\title{
Florisphaera profunda and the origin and diagenesis of carbonate phases in eastern Mediterranean sapropel units
}

\author{
J. Thomson, ${ }^{1}$ D. Crudeli, ${ }^{2,3}$ G. J. de Lange, ${ }^{4}$ C. P. Slomp, ${ }^{4}$ E. Erba, ${ }^{2}$ C. Corselli, ${ }^{5}$ \\ and S. E Calvert ${ }^{6}$
}

Received 27 October 2003; revised 14 April 2004; accepted 13 May 2004; published 14 July 2004.

[1] High relative concentrations of the lower photic zone nannofossil Florisphaera profunda have been reported in all recent eastern Mediterranean sapropels. In the most recent sapropel (S1), high bulk sediment $\mathrm{Sr} / \mathrm{Ca}$ ratios occur along with high $\mathrm{F}$. profunda contents toward the base of the unit, exemplified here in four cores from 1.5-3.5 km water depth. Co-occurring biogenic carbonates contain insufficient $\mathrm{Sr}$ to account for these high Sr concentrations, and X-ray diffraction and selective leaching show that the high $\mathrm{Sr} / \mathrm{Ca}$ ratios are due to aragonite, the $\mathrm{CaCO}_{3}$ polymorph that is rarely preserved in deep marine sediments, with $\sim 1$ wt $\% \mathrm{Sr}$. The possible sources of this aragonite include (1) precipitation with surface ocean production, (2) detrital input from shallow-water sediments by high continental runoff, or (3) postdepositional diagenetic formation driven by increased pore water alkalinity resulting from sulphate reduction. The third formation mechanism for the aragonite is favored, in which case the similarity in the positions of the aragonite and F. profunda abundance maxima in sapropels is probably related to $\mathrm{C}_{\text {org }}$ accumulation and resulting sulphide diagenesis that produces high pore water alkalinity. There is clear micropaleontological evidence that dissolution of the less soluble biogenic low- $\mathrm{Mg} \mathrm{CaCO}_{3}$ is occurring, or has occurred, during early diagenesis in these sediments despite the coexistence of the more soluble high- $\mathrm{Mg}$ calcite and aragonite polymorphs. Similar $\mathrm{Sr} / \mathrm{Ca}$ maxima are also found associated with older sapropels, always located close both to local minima in surface ocean $\delta^{18} \mathrm{O}$ that signal maximum monsoon-driven runoff and to maxima in diagenetic sediment sulphide contents. High freshwater flows from monsoons are believed to drive eastern Mediterranean sapropel formation through water column stabilization that favors $F$. profunda production and later through development of deep water column dysoxia/anoxia because of reduced ventilation. The relative abundances of $F$. profunda are high between 5 and $11{ }^{14} \mathrm{C}$ kyr B.P. with a maximum at $\sim 9{ }^{14} \mathrm{C}$ kyr B.P. The surface ocean production changes marked by F. profunda therefore begin earlier and finish later than the formation of the S1 sapropel, which only develops between 6 and $10{ }^{14} \mathrm{C}$ kyr B.P. INDEX TERMS: 1050 Geochemistry: Marine geochemistry (4835, 4850); 4802 Oceanography: Biological and Chemical: Anoxic environments; 4267 Oceanography: General: Paleoceanography; 4243 Oceanography: General: Marginal and semienclosed seas; 4835 Oceanography: Biological and Chemical: Inorganic marine chemistry; KEYWORDS: sapropel, aragonite, strontium

Citation: Thomson, J., D. Crudeli, G. J. de Lange, C. P. Slomp, E. Erba, C. Corselli, and S. E. Calvert (2004), Florisphaera profunda and the origin and diagenesis of carbonate phases in eastern Mediterranean sapropel units, Paleoceanography, 19, PA3003,

doi:10.1029/2003PA000976.

\section{Introduction}

[2] At present, the surface waters of the eastern Mediterranean are oligotrophic and the entire water column is well oxygenated [Roether and Well, 2001] with the consequence

\footnotetext{
${ }^{1}$ Southampton Oceanography Centre, Southampton, UK.

${ }^{2}$ Department of Earth Sciences, University of Milan, Milan, Italy.

${ }^{3}$ Now at Institute for Geosciences, Christian-Albrechts-Universitat Kiel, Kiel, Germany.

${ }^{4}$ Utrect University, Faculty of Earth Sciences, Utrecht, Netherlands.

${ }^{5}$ Department of Geological Sciences and Geotechnologies, MilanoBicocca University, Milan, Italy.

${ }^{6}$ Department of Earth and Ocean Sciences, University of British Columbia, Vancouver, British Columbia, Canada.
}

Copyright 2004 by the American Geophysical Union. 0883-8305/04/2003PA000976 that $\mathrm{C}_{\text {org }}$-poor $(0.1-0.2 \mathrm{wt} \%)$ sediments are being deposited throughout the deep basin [e.g., van Santvoort et al., 1996, 2002]. In the past, $\mathrm{C}_{\text {org }}$-rich sediments (i.e., sapropels with $\mathrm{C}_{\text {org }}>\sim 2$ wt \%) have formed regularly in the basin at those times when the amplitude of the seasonal cycle of insolation in the Northern Hemisphere was at a maximum [e.g., Calvert, 1983; Wehausen and Brumsack, 2000; Calvert and Fontugne, 2001]. These insolation maxima are determined by minima of the precession component of Earth's orbital cycle and occur every 21 kyr. The trigger mechanism for the basin's repetitive transitions into sapropel formation is believed to be amplification of the African summer monsoon by seasonal radiation forcing [e.g., Rossignol-Strick et al., 1982; Hilgen, 1991; Lourens et al., 1996]. Each episode of sapropel formation has a duration of only a few thousand years, during which time it is believed that 
monsoon runoff leads first to water column stabilization and probably to enhanced production. Deepwater dysoxia or anoxia then develops in the temporarily poorly ventilated deep waters to allow enhanced $\mathrm{C}_{\text {org }}$ preservation and sulphide formation and hence sapropel formation in the sediments [Rohling, 1994]. The repetitive occurrence of sapropels is thus an important example of solar orbital forcing on climatic oscillations and of the amplification of climatic signals in a restricted ocean basin. While sapropel formation is understood at this level of detail, however, the precise mechanisms by which the basin makes the transitions from deposition of $\mathrm{C}_{\text {org }}$-poor to $\mathrm{C}_{\text {org }}$-enriched sediments and back are less well understood. An improved mechanistic understanding is relevant to the debate on the relative importance of preservation versus production in formation of $\mathrm{C}_{\mathrm{org}}$-rich marine sediments, including black shales. It seems likely that such an improved understanding of the eastern Mediterranean basin's behavior will come from multidisciplinary investigations that provide data for more sophisticated paleoenvironmental reconstructions and modeling.

[3] Castradori [1993] first pointed out that, in comparison with their enclosing $\mathrm{C}_{\text {org }}$-poor sediments, the last few eastern Mediterranean sapropels contain unusually high numbers of platelets from Florisphaera profunda, an incertae sedis species [Jordan and Kleijne, 1994] with a marked lower photic zone preference [Okada and Honjo, 1973]. Given that most other calcareous nannofossil species flourish higher in the water column, Castradori [1993] argued that production in sapropel times was likely to have been characterized by primary production occurring unusually deep in the photic zone, likely in a deep chlorophyll maximum (DCM) layer as previously proposed by Rohling and Gieskes [1989]. Subsequent detailed investigations of sapropels in which diatoms had unusually been preserved have further supported the DCM hypothesis [Kemp et al., 1999; Corselli et al., 2002]. Laminations in these same diatomaceous sapropel units also provide evidence for an annual depositional pulse of material to the seafloor at the end of seasonal DCM stratification in autumn [Kemp et al., 2000]. High relative abundances of $F$. profunda are thus interpreted as a persistent carbonate marker of production and water column structure change during times of sapropel formation.

[4] Sapropels, including S1, generally have lower total carbonate contents than their enclosing nannofossil marls. If the ratio of the fluxes of total biogenic production (i.e., opal plus carbonate) to detrital materials does not change materially during sapropel deposition, and if siliceous rather than carbonate production dominates during sapropel episodes, then these lower carbonate contents may be explicable by postdepositional opaline silica dissolution [van Os et al., 1994; Schenau et al., 1999; Kemp et al., 1999, 2000; Corselli et al., 2002]. An unusual feature of eastern Mediterranean sediments is that they contain the more soluble $\mathrm{CaCO}_{3}$ polymorphs high-Mg calcite $(>4 \mathrm{~mol}$ $\% \mathrm{MgCO}_{3}$ ) and aragonite as well as the less soluble low-Mg calcite $\left(<4\right.$ mol $\left.\% \mathrm{MgCO}_{3}\right)$. Low-Mg calcite (subsequently referred to simply as "calcite") is the biogenic polymorph that is generally formed by surface dwelling organisms and is usually the only $\mathrm{CaCO}_{3}$ form found
Table 1. Positions and Water Depths of the Cores Investigated

\begin{tabular}{|c|c|c|c|c|}
\hline Core & $\begin{array}{l}\text { Corer } \\
\text { Type }\end{array}$ & $\begin{array}{c}\text { Water } \\
\text { Depth, }{ }^{\mathrm{a}} \mathrm{m}\end{array}$ & Latitude, ${ }^{\circ} \mathrm{N}$ & Longitude, ${ }^{\circ} \mathrm{E}$ \\
\hline BC19 & box & 2750 & $33^{\circ} 47.85^{\prime}$ & $28^{\circ} 36.50^{\prime}$ \\
\hline LC25 & $\begin{array}{l}\text { large diameter } \\
\text { piston }\end{array}$ & 3060 & $32^{\circ} 36.01^{\prime}$ & $27^{\circ} 23.25^{\prime}$ \\
\hline SL60 & piston & 1522 & $35^{\circ} 39.69^{\prime}$ & $26^{\circ} 34.99^{\prime}$ \\
\hline SL114 & box & 3390 & $35^{\circ} 17.24^{\prime}$ & $21^{\circ} 24.52^{\prime}$ \\
\hline T87-19B & box & 3483 & $36^{\circ} 48.9^{\prime}$ & $19^{\circ} 10.7^{\prime}$ \\
\hline MD84641 & piston & 1375 & $33^{\circ} 02^{\prime}$ & $32^{\circ} 38^{\prime}$ \\
\hline
\end{tabular}

${ }^{\mathrm{a}}$ Units are uncorrected.

preserved in deepwater sediments. The deep ocean is under-saturated with respect to high-Mg calcite and aragonite, so these polymorphs generally dissolve before or immediately after deposition in deepwater open-ocean sediments [Friedman, 1965; Berner and Honjo, 1981; Fabry and Deuser, 1991]. High-Mg calcite and aragonite are therefore usually only found in sediments under waters where the carbonate system is over-saturated, i.e., at shallow water depth and/or at low latitudes [Kinsman, 1969; Wilkinson and Given, 1986], and the high-Mg calcites found in the eastern Mediterranean marls are believed to be diagenetic [Milliman and Müller, 1973; Aksu et al., 1995; Calvert and Fontugne, 2001].

[5] In this paper, geochemical and micropaleontological analyses are reported that show that high $\mathrm{Sr} / \mathrm{Ca}$ ratios in the most recent sapropel (S1) appear to be coherent with high $F$. profunda abundances. This $\mathrm{Sr}$ enrichment cannot be introduced into the sediment with biogenic calcites, but it is instead shown to be due to the presence of aragonite. In these sediments, aragonite is also mostly confined to sapropels, while high- $\mathrm{Mg}$ calcite is mostly restricted to the intercalated marls. These associations are described and mechanisms proposed for the formation of the carbonate phases in the context of sapropel development.

\section{Methods}

[6] The positions and water depths of the investigated cores in the eastern Mediterranean basin are specified in Table 1 and displayed in Figure 1. For calcareous nannofossil analyses, a small amount of sediment was moistened with distilled water, smeared homogeneously on a slide, and permanently mounted with optical adhesive. No centrifugation or ultrasound cleaning was applied in order to retain the original fine fraction composition. Analyses were performed on 192 samples (cores SL114, SL60, BC19, and LC25) by a cross-polarized light microscope (LM) at 1250 times magnification. The occurrences of the lower photic zone species $F$. profunda, Gladiolithusflabellatus, and Algirosphaerarobusta were counted separately from upper/middle photic zone species. Their abundance was recorded against 100 coccoliths of all other species following the concepts of Matsuoka and Okada [1989] and Castradori [1993], so the reported data are index values. Both $F$. profunda var. profunda and $F$. profunda var. elongata, present in the modern Mediterranean Sea [Cros, 2002], were observed in these sediments, but the plates were not distinguished at the variety level during LM counting. 


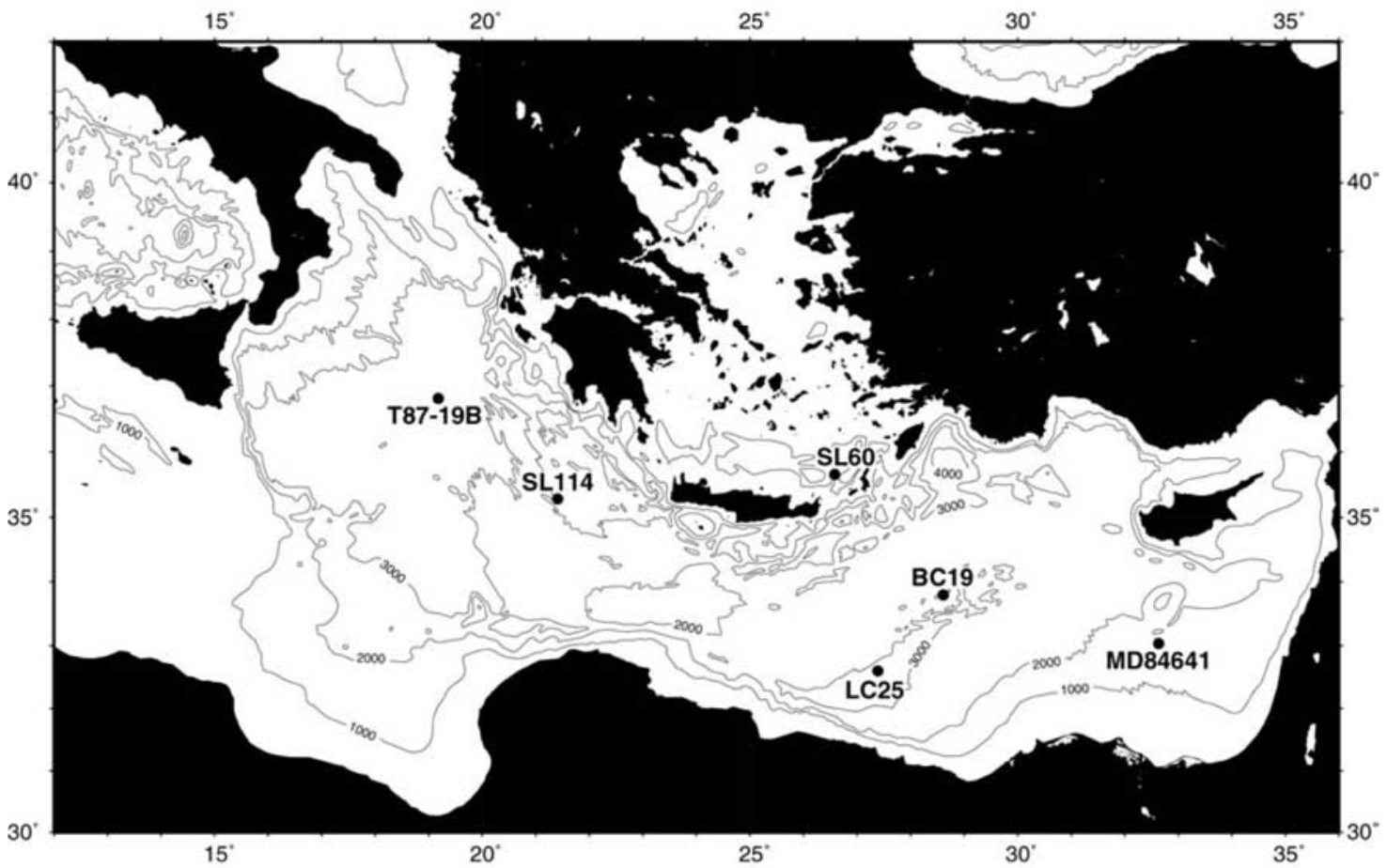

Figure 1. Map of the eastern Mediterranean Sea with the positions of the cores discussed in the text. Contours are at $1000 \mathrm{~m}$

Following Kleijne [1992], all specimens of the genus Algirosphaera were assigned to A. robusta.

[7] The inorganic geochemical data available were from cores that had been analyzed in different laboratories at different times, either by X-ray fluorescence (XRF) analysis of fusion beads or compressed powder pellets for major and minor elements, respectively [Mercone et al., 2000], or by inductively coupled plasma atomic emission spectroscopy (ICP-AES) analysis of dissolved (with $\mathrm{HF} / \mathrm{HClO}_{4}$ acids) or fused $\left(\mathrm{LiBO}_{2}\right)$ samples for both minor and major elements [van Santvoort et al., 1996]. Organic carbon and $\mathrm{CaCO}_{3}$ were determined coulometrically from released $\mathrm{CO}_{2}$ [Mercone et al., 2000], with inorganic C (biogenic calcium carbonate) measured as the $\mathrm{CO}_{2}$ evolved by the addition of $10 \%(\mathrm{v} / \mathrm{v}) \mathrm{H}_{3} \mathrm{PO}_{4}$ and total $\mathrm{C}$ measured as the $\mathrm{CO}_{2}$ generated by total sample combustion at $900^{\circ} \mathrm{C}$. Selected samples including some with high $\mathrm{Sr}$ contents were investigated by X-ray diffraction (XRD) to determine the proportions of the different $\mathrm{CaCO}_{3}$ polymorphs and by mild leaching with 1 molar acetic acid to separate carbonate (dissolved in the leachate) from detrital phases (left as the leaching residue). Analysis for a full suite of elements was then performed on the leachates by ICP-AES, and the residues were fused with lithium metaborate, dissolved, and similarly analyzed by ICP-AES. In both cases the analyses were calibrated with matrix-matched standards, and the residue analyses were confirmed by including the international standard reference material MAG-1 (marine mud). Four or five AMS radiocarbon analyses from planktonic foraminifera $>150 \mu \mathrm{m}$ were obtained in and around each sapropel unit in order to convert depth in core to radiocarbon time [Mercone et al., 2000].

[8] Selected samples from cores LC25 and T87-19B with high $\mathrm{Sr} / \mathrm{Ca}$ values were also examined by scanning electron microscopy (SEM) at Kiel and Utrecht in an attempt to discriminate between biological and inorganic/diagenetic precipitates. Filter preparation for SEM study was based on a modification of the method of Andruleit [1996]: $0.05 \mathrm{~g}$ of wet sediment was diluted with ethanol, ultrasonified for $5 \mathrm{~s}$, and split in 10 aliquots with a rotary splitter. The suspension ( $0.005 \mathrm{~g}$ of sediment) was filtered on to a polycarbonate membrane filter $(0.4 \mu \mathrm{m}$ pore size; $50 \mathrm{~mm}$ diameter $)$ and dried for 2 hours at $50^{\circ} \mathrm{C}$. A segment from each filter was mounted on a SEM stub and coated with $\mathrm{Au} / \mathrm{Pd}$. Selected stubs that had been examined by SEM were also reanalyzed by ion microprobe at Utrecht in order to determine the $\mathrm{Sr} / \mathrm{Ca}$ ratios in the different carbonate particle morphologies that had been identified by SEM.

\section{Results and Discussion}

\subsection{Sr/Ca, S, and Florisphaera Profunda Profiles Compared}

[9] Postdepositional oxidation has affected the upper reaches of many sapropel S1 units such that their present visual thickness is typically several centimeters thinner than their inferred original thickness [Higgs et al., 1994; Thomson et al., 1995; van Santvoort et al., 1996] (Figure 2). The limits of the original sapropel S1 units are therefore defined from the whole sediment $\mathrm{Ba} / \mathrm{Al}$ profiles on 

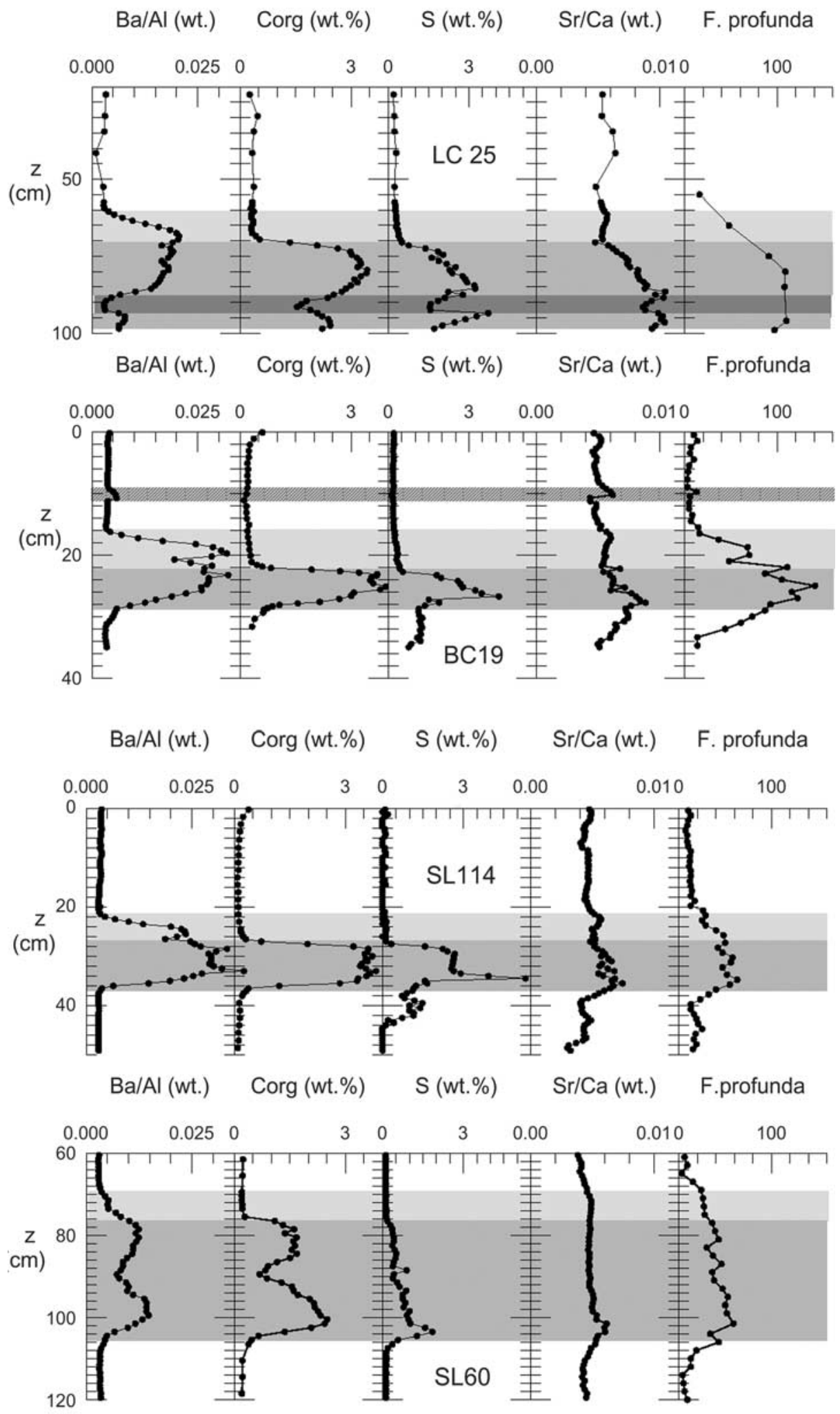

Figure 2. Downcore profiles of $\mathrm{Ba} / \mathrm{Al}$ (wt ratio), total $\mathrm{C}_{\text {org }}$ and total $\mathrm{S}$ (wt \%), $\mathrm{Sr} / \mathrm{Ca}$ (wt ratio), and Florisphaera profunda index (number of specimens per 100 other coccoliths counted) for cores LC25, and BC19, SL114, and SL60. The oxidized and unoxidized parts of the S1 sapropel are indicated by light and dark shading, a thin turbidite in core LC25 and an ash layer in core BC19 are marked by dark shading. The $F$. profunda profile for core $\mathrm{BC} 19$ was obtained from a different subcore that was $2.5 \mathrm{~cm}$ shorter to the base of the sapropel than the subcore used for geochemical analysis. 


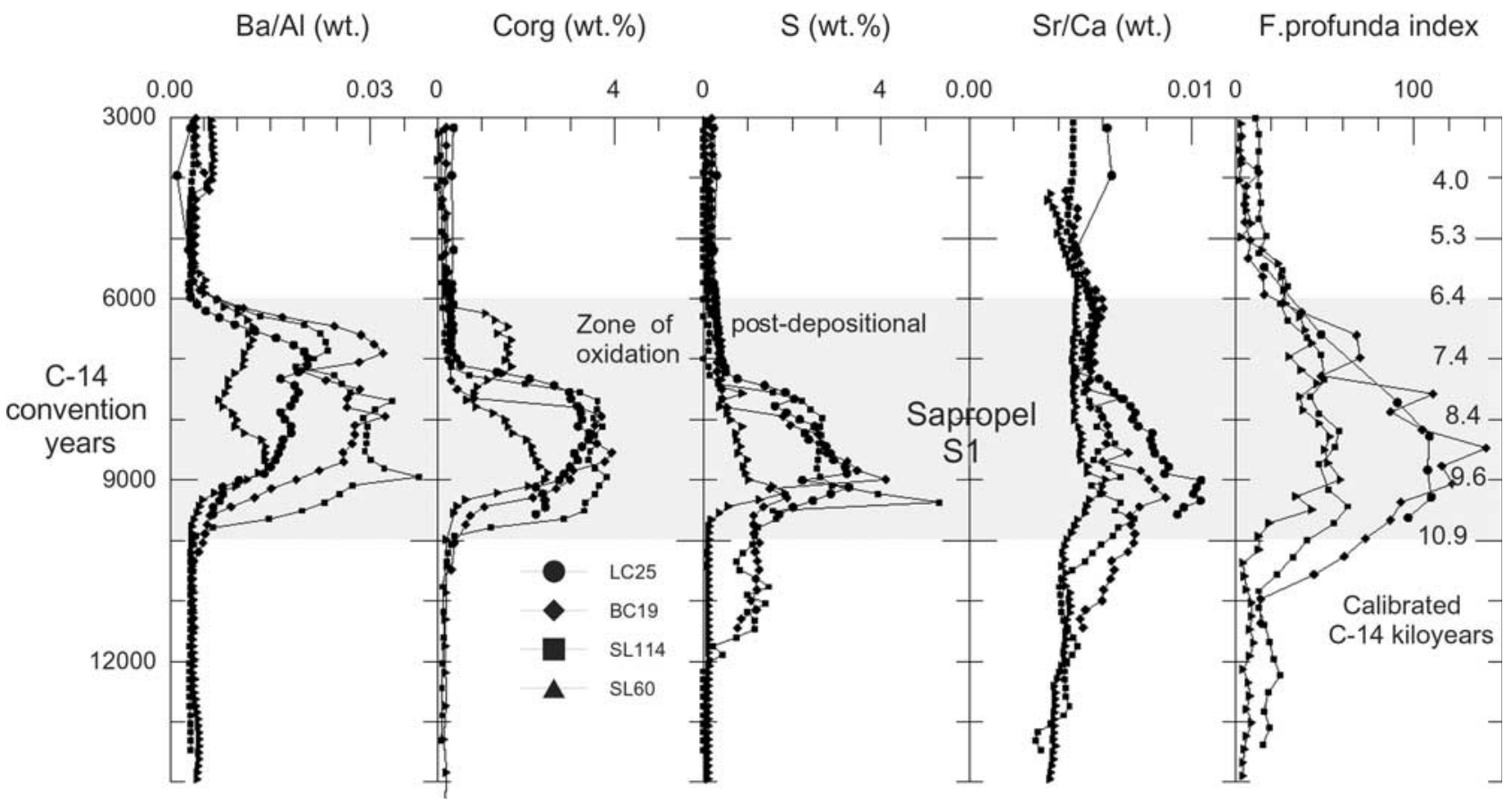

Figure 3. $\mathrm{Ba} / \mathrm{Al}$ (wt ratio), $\mathrm{C}_{\text {org }}$ (wt \%), $\mathrm{S}$ (wt \%), $\mathrm{Sr} / \mathrm{Ca}$ (wt ratio), and $F$. profunda index versus a ${ }^{14} \mathrm{C}$ convention years timescale for cores LC25, BC19, SL114, and SL60. The timescales were obtained by regression of $\mathrm{C}^{14}$ ages in and around sapropel $\mathrm{S} 1$ on depth in each core. In this case the shaded area between 6 and $10{ }^{14} \mathrm{C}$ kyr B.P. covers the period of enhanced $\mathrm{Ba} / \mathrm{Al}$ values, but sapropel with high $\mathrm{C}_{\text {org }}$ and $\mathrm{Ba} / \mathrm{Al}$ values is present for a lesser time $\left(\sim 6.5-9.5{ }^{14} \mathrm{C}\right.$ kyr B.P.), while $F$. profunda values are high between 5 and $11 \mathrm{C}$ kyr B.P. Note that postdepositional oxidation has affected the $\mathrm{C}_{\text {org }}$ and $\mathrm{S}$ contents of sediments laid down after $\sim 7.5{ }^{14} \mathrm{C}$ kyr B.P. in cores LC25, BC19, and SL114. The scale on the far left is the Stuiver and Braziunas [1993] conversion of marine ${ }^{14} \mathrm{C}$ convention ages to calibrated time with a constant fixed surface ocean reservoir age of 400 years.

the premises that (1) the biogenic $\mathrm{Ba}$ that accompanies deposited $\mathrm{C}_{\text {org }}$ during sapropel formation increases $\mathrm{Ba} / \mathrm{Al}$ over a detrital value of $0.0030-0.0035$ and (2) that $\mathrm{Ba} / \mathrm{Al}$ is a more persistent indicator than $\mathrm{C}_{\text {org }}$ because it does not undergo the postdepositional oxidation and remineralization that results in $\mathrm{C}_{\text {org }}$ loss from the sapropel [Thomson et al., 1999; Rutten and de Lange, 2002].

[10] As will be seen later, the $\mathrm{Sr} / \mathrm{Ca}$ mass ratio of deepsea carbonate marls is generally around $0.004-0.005$, but higher values are measured consistently in S1 units. There appear to be similarities in the positions and possibly the shapes of the profiles of whole sediment $\mathrm{Sr} / \mathrm{Ca}$ ratio, whole sediment $\mathrm{S}$ content, and $F$. profunda relative abundance profiles through these sapropel units (Figure 2). This is demonstrated with profiles from two cores with the largest $F$. profunda index and $\mathrm{Sr} / \mathrm{Ca}$ ratio excursions encountered, BC19 and LC25 with maximum values $>100$ for the $F$. profunda index and $0.009-0.01$ for $\mathrm{Sr} / \mathrm{Ca}$, and two further cores, SL60 and SL114 with peak F. profunda index values of $\sim 60$ and $\mathrm{Sr} / \mathrm{Ca}$ mass ratios of $0.006-0.007$. The magnitudes of the $F$. profunda index and $\mathrm{Sr} / \mathrm{Ca}$ values thus increase together, but they do not appear to be directly proportional to $\mathrm{C}_{\mathrm{org}}$ contents. Negri and Giunta [2001] and A. Rutten and G. J. de Lange (Sequential extraction of aragonite/calcite and dolomite from eastern Mediterranean sediments, submitted to Marine Geology, 2004, hereinafter referred to as Rutten and de Lange, submitted manuscript, 2004) have previously reported similar $F$. profunda and $\mathrm{Sr} / \mathrm{Ca}$ profile shapes through sapropel S1, respectively.

[11] Data from different S1 units can be compared directly if a few radiocarbon ages from in and around each sapropel are available [Mercone et al., 2000]. This comparison is achieved by regressing the accelerator mass spectrometric (AMS) radiocarbon ages of planktonic foraminifera on their depth in core in order to construct an independent timescale for each core. This procedure avoids selection of a reservoir age correction for the Mediterranean area that is necessary to convert radiocarbon convention ages to calibrated time [Reimer and McCormac, 2002; Keenan, 2002] but has the drawback that marine radiocarbon convention ages do not have an exact linear relation with true time [Stuiver and Braziunas, 1993]. When the four core profiles of Figure 2 are placed on such a radiocarbon timescale (Figure 3), a consistent picture emerges. The enhanced $F$. profunda and $\mathrm{Sr} / \mathrm{Ca}$ values reach their maxima toward the base of high $\mathrm{Ba} / \mathrm{Al}$ (and residual $\mathrm{C}_{\mathrm{org}}$ ) values, and high $F$. profunda and $\mathrm{Sr} / \mathrm{Ca}$ values occur 


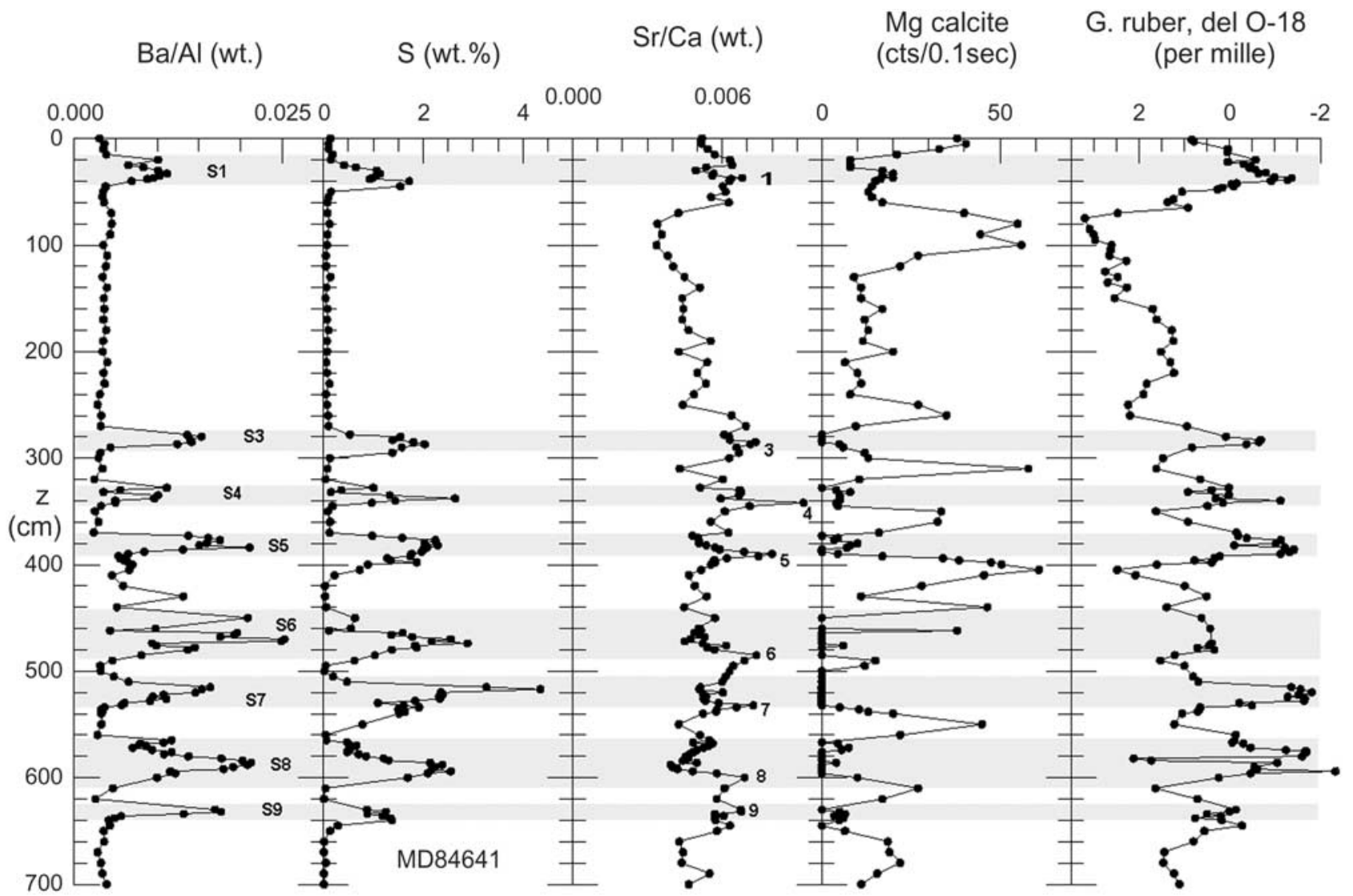

Figure 4. Downcore profiles of $\mathrm{Ba} / \mathrm{Al}$ (wt ratios), total $\mathrm{S}$ (wt \%), $\mathrm{Sr} / \mathrm{Ca}$ (wt ratio), high-Mg calcite (relative XRD measure, counts per $0.1 \mathrm{~s}$ ), and $\delta \mathrm{O}^{18}$ from foraminifer G. ruber for core MD848641 [Kallel et al., 1997, 2000; Calvert and Fontugne, 2001]. Sapropels are identified on the basis of high Ba/Al ratios and indicated by light shading.

consistently over a longer time than the $\mathrm{S} 1$ unit defined by the $\mathrm{Ba} / \mathrm{Al}$ ratio. (Note that, as indicated in Figure 2, the $\mathrm{C}_{\text {org }}$ and $\mathrm{S}$ profiles in the upper parts of the $\mathrm{S} 1$ units in Figure 3 have suffered loss from postdepositional oxidation. This has affected sediments laid down after $\sim 7.5{ }^{14} \mathrm{C}$ kyr B.P. in cores LC25, BC19, and SL114.)

\subsection{Geochemical Evidence From Older Sapropel Units}

[12] The cyclicity of sapropel formation in the eastern Mediterranean suggests that similarities might be found between S1 and older sapropels. Core MD84641, located approximately midway between the Nile delta and Cyprus, has been used to demonstrate the distinct decrease in salinity experienced by the surface waters of the eastern Mediterranean basin during formation of the last several sapropels [Kallel et al., 1997, 2000] and that marked compositional contrasts exist between sapropels and the enclosing marl sediments [Calvert and Fontugne, 2001]. In this core, $\mathrm{Sr} / \mathrm{Ca}$ values in a background range of $0.004-$ 0.005 are observed between sapropels, coincident with those sections where high $\mathrm{Mg}$-calcite levels are present (Figure 4). Higher $\mathrm{Sr} / \mathrm{Ca}$ values (of a magnitude similar to or greater than those measured in S1) are found at each of the sapropels S1, S3, S4, S5, S6, S7, S8, and S9, and aragonite is detected in the XRD scans of these samples (not shown). Within the resolution of sampling, maximum $\mathrm{Sr} / \mathrm{Ca}$ values (always >0.006) occur at every sapropel either within or at the base of the high $\mathrm{Ba} / \mathrm{Al}$ values and close to the maximum diagenetic $\mathrm{S}$ (sulphide) values developed in each sapropel. Zones with high-Mg calcite content thus alternate with zones of high $\mathrm{C}_{\text {org }}, \mathrm{Ba} / \mathrm{Al}$, $\mathrm{Sr} / \mathrm{Ca}$, and $\mathrm{S}$ values (i.e., the sapropels; Figure 4). Low but finite values of high-Mg calcite values are present in sapropel S1, and these values are higher than those in any of the older sapropels.

[13] Most of the $\mathrm{Sr} / \mathrm{Ca}$ peak values in core MD84641 also occur close to depths where the planktonic foraminifer Globigerinoides ruber records low $(<0.0 \%$ ) surface ocean $\delta^{18} \mathrm{O}$ values, as discussed by Kallel et al. [1997, 2000]. The single exception is sapropel S6, formed in glacial times, where the lowest $\delta^{18} \mathrm{O}$ value is $+0.5 \%$. In this basin, such low surface ocean $\delta^{18} \mathrm{O}$ values are due to the runoff from heavily fractionated monsoon rains that drive the environmental changes that cause the episodes of sapropel formation [Kallel et al., 1997; Rohling, 1999; Bar-Matthews et al., 2000; Gasse, 2002; Bard et al., 2002]. Since the original report of Castradori [1993], it has also been shown 


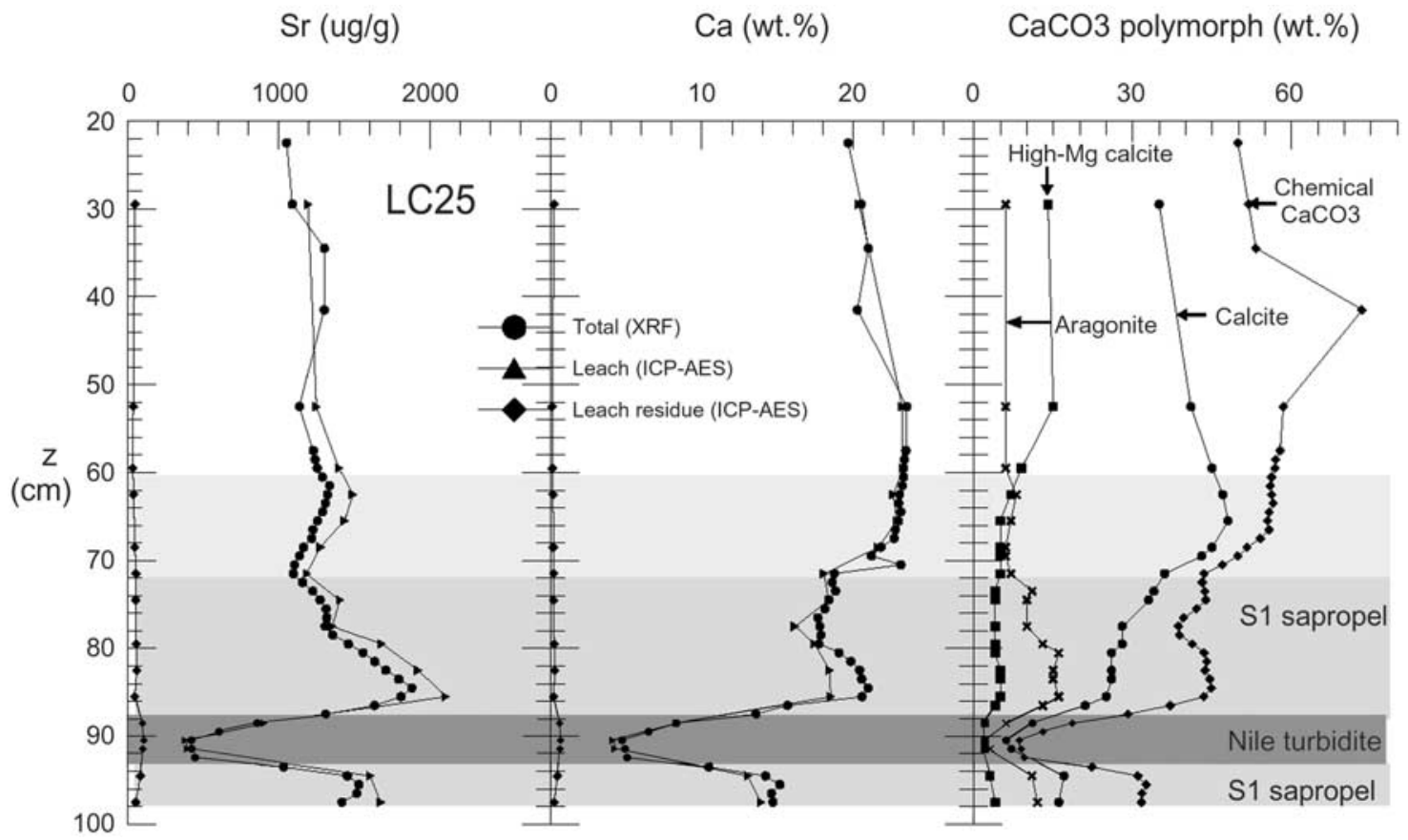

Figure 5. Leach experiment and X-ray diffraction data profiles for core LC25. (left) Total data (XRF), leached and detrital data (ICP-AES) for $\mathrm{Sr}\left(\mu \mathrm{g} \mathrm{g}^{-1}\right)$. (middle) Total data (XRF), leached and detrital data (ICP-AES) for $\mathrm{Ca}$ (wt \%). (right) Coulometric data for total $\mathrm{CaCO}_{3}$ and $\mathrm{XRD}$ data for aragonite, high-Mg calcite, and calcite. The oxidized and unoxidized parts of the S1 sapropel are indicated by light and dark shading, and a thin turbidite in sapropel S1 is marked by darker shading.

that all the sapropels present in core MD84641 and much older sapropels also display increased $F$. profunda abundances [Castradori, 1998; Negri et al., 1999; Negri and Giunta, 2001; Corselli et al., 2002].

\subsection{Source of the Additional Sr}

[14] Distinctly different mechanisms can be invoked to link high $\mathrm{Sr} / \mathrm{Ca}$ values to $F$. profunda abundance or $\mathrm{S}$ content but cause and effect uncertainties arise because maxima in signals of preserved production ( $F$. profunda, Ba/Al, and $\mathrm{C}_{\text {org }}$ ), induced diagenesis ( $\mathrm{S}$ as sulphide from sulphate reduction by $\mathrm{C}_{\text {org }}$ ), and $\mathrm{Sr} / \mathrm{Ca}$ all occur close together in sapropels (Figure 3). A priori, the obvious possibilities are that the extra $\mathrm{Sr}$ relative to $\mathrm{Ca}$ is contributed by $F$. profunda or another component with a flux closely related to that of $F$. profunda or is diagenetic but related to surface ocean production as traced by $F$. profunda.

[15] The first requirement is to identify the host phase for the additional $\mathrm{Sr}$ observed in sapropels. One possibility is preservation of celestite $\left(\mathrm{SrSO}_{4}\right)$ from acantharia in the sediments, but this seems unlikely in view of the high solubility of celestite [Reardon and Armstrong, 1987; Bernstein et al., 1992, 1998]. No acantharia were identified during micropaleontological analyses, and celestite was not identified in XRD analysis. Marine barite has a variable $\mathrm{Sr}$ content, and $\mathrm{SrSO}_{4}$ molar fractions as high as 0.26 have been reported [Dehairs et al., 1980; Bertram and Cowen, 1997; Rushdi et al., 2000]. There is, however, insufficient barite for $\mathrm{Sr}$ in barite to dominate the $\mathrm{Sr} / \mathrm{Ca}$ ratio in these sediments with a $\mathrm{CaCO}_{3}$ content of $40-50$ wt $\%$, and the shapes of the $\mathrm{Sr} / \mathrm{Ca}$ and $\mathrm{Ba} / \mathrm{Al}$ profiles are quite different (Figure 3).

[16] In shallow-water marine carbonates, increased $\mathrm{Sr}$ relative to $\mathrm{Ca}$ often implies that a proportion of the total $\mathrm{CaCO}_{3}$ is present as aragonite rather than calcite [Kinsman, 1969], and aragonite was detected in those levels of core MD 84641 where the highest $\mathrm{Sr} / \mathrm{Ca}$ values were detected. The nature of the $\mathrm{Sr}$ association was therefore investigated in the core with the highest $\mathrm{Sr} / \mathrm{Ca}$ values (LC25) by mild acid leaching of the whole sediment to yield carbonate and detrital aluminosilicate fractions (Figure 5). Excluding samples from the thin Nile turbidite that interrupts S1 in this core [Reeder et al., 1998], the acetic acid leach residue representing detrital aluminosilicate material has a $\mathrm{Sr}$ content in the range $34-95 \mu \mathrm{g} \mathrm{g}^{-1}$, or $77-122 \mu \mathrm{g} \mathrm{g}^{-1}$ on a carbonate-free basis. Rutten and de Lange (submitted manuscript, 2004) have reported even lower detrital aluminosilicate $\mathrm{Sr}$ contents $\left(21-47 \mu \mathrm{g} \mathrm{g}^{-1}\right)$ after multistep leaching of recent eastern Mediterranean sediments including sapropel S1. Detrital aluminosilicate Sr thus makes a minor contribution to the total Sr content of these sediments $\left(1000-1800 \mu \mathrm{g} \mathrm{g}^{-1}\right)$, and most of the Sr present appears to be associated with carbonate.

[17] XRD analysis revealed that aragonite is present throughout the sampled section of core LC25 in variable amounts, increasing from $\sim 5 \mathrm{wt} \%$ of the total sediment in the marls above the sapropel to $\sim 15 \mathrm{wt} \%$ in the sapropel itself, and it is those samples with the highest aragonite contents that show the highest $\mathrm{Sr}$ contents and $\mathrm{Sr} / \mathrm{Ca}$ values (Figure 5). High-Mg calcite has an abundance pattern 


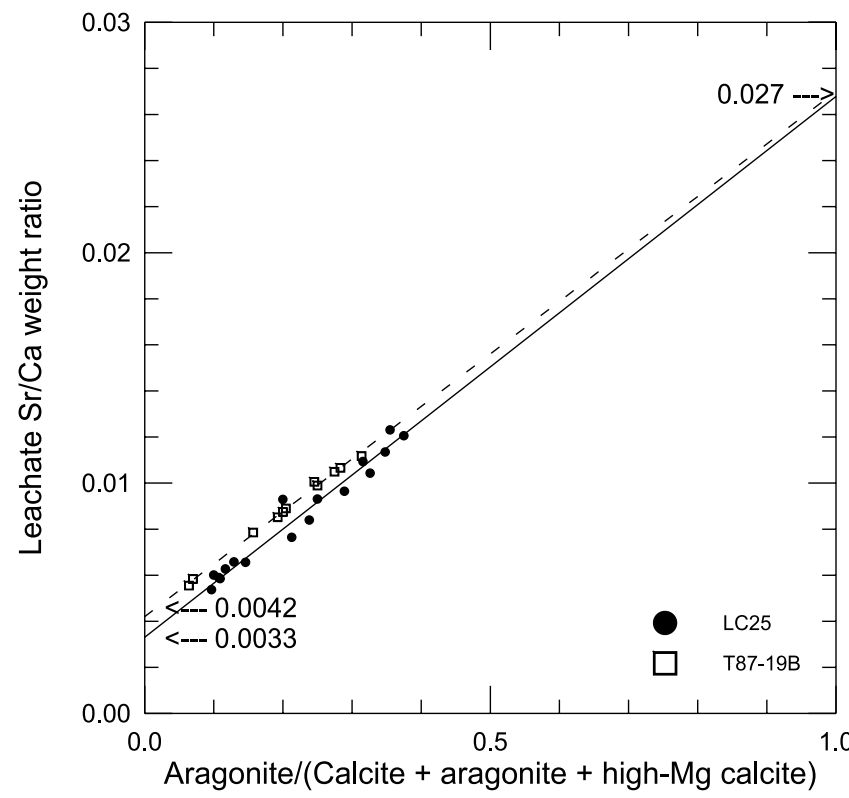

Figure 6. Leach fraction $\mathrm{Sr} / \mathrm{Ca}$ data (ICP-AES) for selected samples of core LC25 versus aragonite fraction of total $\mathrm{CaCO}_{3}$ (sum of XRD aragonite, high-Mg calcite, and calcite), shown as filled circles. The orthogonal best fit line is solid and shown along with zero and unity aragonite end-member values. Similar data from samples of the Augias turbidite in core T87-19B are also displayed as open squares and with a dashed fit line.

opposite to that of aragonite, decreasing from $\sim 15 \%$ of the total sediment in the overlying marls to $<5 \%$ within the sapropel. From the core MD84641 and LC25 XRD data (Figures 4 and 5), this alternation of high-Mg calcite preferentially in the marls and aragonite preferentially in the sapropels therefore appears to be general in eastern Mediterranean sediments. Between them, aragonite and high-Mg calcite contribute $20-50 \%$ of the total $\mathrm{CaCO}_{3}$ in core LC25. This paper focuses on Sr and aragonite rather than on $\mathrm{Mg}$ and high-Mg calcite because the relatively high $\mathrm{Mg}$ content of detrital aluminosilicates means that the $\mathrm{Mg}$ content is divided more evenly between the aluminosilicate and carbonate phases than is the $\mathrm{Sr}$ content. The XRD and leachate data from core LC25 samples can be combined to derive a relationship of leachate $\mathrm{Sr} / \mathrm{Ca}$ with carbonate mineralogy (Figure 6), which indicates a pure aragonite end-member with $\mathrm{Sr} / \mathrm{Ca}$ wt ratio $=0.027\left(10,700 \mu \mathrm{g} \mathrm{Sr} \mathrm{g}^{-1}\right.$ $\left.\mathrm{CaCO}_{3}\right)$ and a zero aragonite end-member with $\mathrm{Sr} / \mathrm{Ca}=$ $0.0033\left(1340 \mu \mathrm{g} \mathrm{Sr} \mathrm{g}^{-1} \mathrm{CaCO}_{3}\right)$. This contrast implies that the $\mathrm{Sr} / \mathrm{Ca}$ ratio will be double that of the zero aragonite endmember when $15 \%$ of the total $\mathrm{CaCO}_{3}$ is present as aragonite.

[18] The observed range of $\mathrm{Sr} / \mathrm{Ca}$ variations in Figure 6 is much larger than those encountered in investigations of $\mathrm{Sr} / \mathrm{Ca}$ in separated and cleaned foraminiferal and coccolith calcite [e.g., Stoll and Schrag, 1999; Shen et al., 2001]. Stoll and Schrag [1999] measured $\mathrm{Sr} / \mathrm{Ca}$ molar ratios in foraminiferal and coccolith calcites of $\sim 1.3 \times 10^{-3}$ and $\sim 2.2 \times 10^{-3}(\mathrm{Sr} / \mathrm{Ca}$ wt ratios $=0.0028$ and $0.0048 ; 1100$ and $1900 \mu \mathrm{g} \mathrm{Sr} \mathrm{g}^{-1} \mathrm{CaCO}_{3}$ ), respectively, in a sediment with a bulk carbonate $\mathrm{Sr} / \mathrm{Ca}$ ratio of $1.8 \times 10^{-3}(\mathrm{Sr} / \mathrm{Ca}$ wt ratio $\left.=0.0039 ; 1600 \mu \mathrm{g} \mathrm{Sr} \mathrm{g}^{-1} \mathrm{CaCO}_{3}\right)$. Subsequent work has confirmed that the $\mathrm{Sr} / \mathrm{Ca}$ range for various coccoliths either separated from sediment or grown in culture is in the range $2-6 \times 10^{-3} \mathrm{~mol}$ [Rickaby et al., 2002; Stoll and Zivieri, 2002], and specifically the $\mathrm{Sr} / \mathrm{Ca}$ ratio of a F. profunda fraction separated from all other coccoliths by differential size settling corresponds to $\sim 1900 \mu \mathrm{g} \mathrm{Sr} \mathrm{g}^{-1}$ $\mathrm{CaCO}_{3}$ [Stoll and Ziveri, 2002]. F. profunda and all other coccolith or foraminiferal calcites cannot be the source of the observed increases in aragonite and $\mathrm{Sr}$ content.

[19] Biogenic aragonite often, but not invariably, contains much more $\mathrm{Sr}$ than biogenic calcite. As examples, the $\mathrm{Sr} / \mathrm{Ca}$ molar ratio in the aragonite of the scleractinian hermatypic coral Porites lobata is $\sim 9.2 \times 10^{-3}(\mathrm{Sr} / \mathrm{Ca}$ wt ratio $=0.021$; $8100 \mu \mathrm{g} \mathrm{Sr} \mathrm{g}^{-1} \mathrm{CaCO}_{3}$; Beck et al. [1992]), whereas in the calcareous green alga Halimeda, it is $\sim 10.9 \times 10^{-3}(\mathrm{Sr} / \mathrm{Ca}$ wt ratio $=0.024 ; 9500 \mu \mathrm{g} \mathrm{Sr} \mathrm{g}^{-1} \mathrm{CaCO}_{3} ;$ Delaney et al. [1996]). Recrystallization in corals and Halimeda has been shown to produce early diagenetic aragonite with somewhat higher $\mathrm{Sr} / \mathrm{Ca}$ values than the original biogenic aragonite at $\sim 10,000 \mu \mathrm{g} \mathrm{Sr} \mathrm{g}^{-1} \mathrm{CaCO}_{3}$ [Müller et al., 2001; RibaudLaurenti et al., 2001], similar to the $\mathrm{Sr} / \mathrm{Ca}$ in aragonite cements [Kinsman, 1969]. Pteropod aragonite accounts for at least $12 \%$ of the total sinking $\mathrm{CaCO}_{3}$ flux in the open ocean, mainly in the large $(>1 \mathrm{~mm})$ size fraction [Berner and Honjo, 1981; Fabry and Deuser, 1991]. It is not possible to explain the data of Figures 5 and 6 by means of pteropod aragonite, however, because unlike coral, algal, or precipitated inorganic aragonite, pteropods have a Sr content no greater than that of biogenic calcites at $1000-1500 \mu \mathrm{g} \mathrm{Sr} \mathrm{g}^{-1}$ $\mathrm{CaCO}_{3}$ [Krinsley and Bieri, 1959; Kinsman, 1969].

\subsection{Mechanisms for Aragonite in Eastern Mediterranean Sapropels and Paleoceanographic Implications}

[20] Three hypotheses to account for the presence of high$\mathrm{Sr}$ aragonite in eastern Mediterranean sapropels are presented and examined using the data above and constraints imposed on the likely scenarios by other paleoceanographic information.

\subsubsection{Aragonite Production Accompanies}

\section{Florisphaera Profunda Production in Surface Waters}

[21] This hypothesis posits that aragonite precipitation is directly linked to monsoonally driven surface ocean production. This is analogous to one set of mechanisms that has been invoked to explain whitings, the drifting patches of very fine $\mathrm{CaCO}_{3}$ turbidity (mainly aragonite) observed suspended in the water column over shallow subtropical carbonate banks. Some workers have ascribed whitings on the Bahama Banks to a biological or chemical precipitation of fine-grained aragonite in the water column [e.g., Shinn et al., 1989; Robbins and Blackwelder, 1992; Macintyre and Reid, 1992; Milliman et al., 1993]. Robbins and Blackwelder [1992] have specifically proposed that whitings result from the precipitation of $\mathrm{CaCO}_{3}$ by picoplankton in the water column.

[22] Friedman [1993, 1994] noted the importance of a proper interpretation of whitings and proposed the Dead Sea as the type locality for abiotic chemical precipitation. It has recently been claimed, however, that the early interpretation of the mechanism for aragonite precipitation events in the 


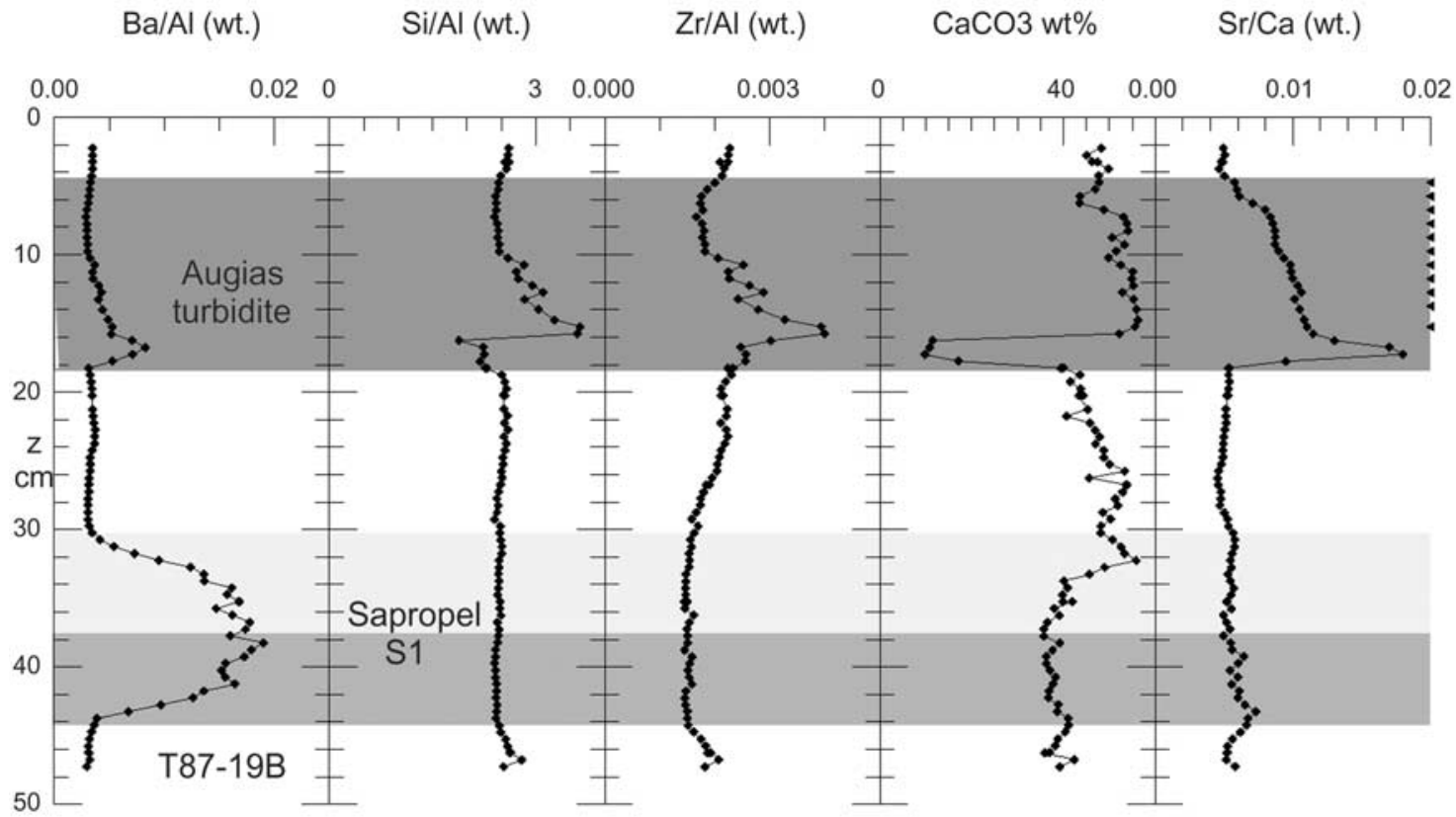

Figure 7. Downcore profiles of $\mathrm{Ba} / \mathrm{Al}, \mathrm{Si} / \mathrm{Al}, \mathrm{Zr} / \mathrm{Al}$ (all wt ratios), $\mathrm{CaCO}_{3}$ (wt \%), and $\mathrm{Sr} / \mathrm{Ca}$ (wt ratio) for core T87-19B. The oxidized and unoxidized parts of the $\mathrm{S} 1$ sapropel are indicated by light and dark shading between 30 and $44 \mathrm{~cm}$, and the Augias turbidite is marked by darker shading from 4.5 to $18.5 \mathrm{~cm}$. The positions of turbidite samples selected for leaching (Figure 6) are indicated by triangles on the far right. (Note that higher $\mathrm{Sr} / \mathrm{Ca}$ values are associated with sapropel $\mathrm{S} 1$ from 29 to $45 \mathrm{~cm}$, with the maximum value at $43 \mathrm{~cm}$, close to the sapropel base.)

Dead Sea is incorrect. Rather than summer evaporation and warming of the $\mathrm{CaCl}_{2}$-enriched Dead Sea brine causing aragonite precipitation as initially envisaged, Barkan et al. [2001] suggest instead that aragonite is precipitated after winter flooding when a riverine fresh water layer enriched in $\mathrm{HCO}_{3}^{-}$overlies and gradually mixes with the underlying $\mathrm{Ca}^{2+}$-rich Dead Sea brine. These workers propose that similar conjunctions of two different water bodies, one with high $\mathrm{Ca}^{2+}$ and the other with high $\mathrm{HCO}_{3}^{-}$, may also promote $\mathrm{CaCO}_{3}$ precipitation in other aquatic environments. Calcium carbonate formation induced by phytoplankton growth is indeed observed in lakes, although in these cases it is generally calcite that is formed [e.g., Thompson et al., 1997; Dittrich et al., 2004].

[23] Eastern Mediterranean salinities are much lower than those of the Dead Sea, but in so far as the scenario described above is similar to sapropel formation during monsoon episodes, the production hypothesis envisages $F$. profunda growth and aragonite formation occurring together at the base of the fresher surficial layer, possibly through picoplankton biomineralization [Robbins and Blackwelder, 1992]. This fine material would be removed from the water column along with settling particulate matter [Deuser et al., 1981, 1983]. The problem with this explanation is that no biogenic high-Sr aragonitic form could be identified in the sediments.

\subsubsection{Aragonite Is Detrital}

[24] A different hypothesis links the high $\mathrm{Sr} / \mathrm{Ca}$ in sapropels to an introduction of detrital aragonite with the mon- soonal floodwaters that initiate and sustain DCM formation and hence favor the production of $F$. profunda. This hypothesis is analogous to the proposition that bottom sediment resuspension (rather than precipitation in the water column) is the explanation for whiting formation on the Bahama Banks [Morse et al., 1984, 2003; Boss and Neumann, 1993; Broecker et al., 2000, 2001].

[25] One unequivocally detrital aragonite occurrence in the eastern Mediterranean is the Augias turbidite that floors the Sirte and Ionian abyssal plains [Hieke and Werner, 2000; Cita and Aloisi, 2000]. This turbidite is formed from sediments from shallow (photic zone) waters in the Gulf of Sirte and has an aragonite content of up to $15 \%$ ascribed to the green alga Halimeda out of a total carbonate content of 50-60\% [Hieke and Werner, 2000]. Although the Augias turbidite is $>12 \mathrm{~m}$ thick on the Ionian Plain floor [Hieke and Werner, 2000], it is only $\sim 14 \mathrm{~cm}$ thick in core T87-19B [Rasmussen, 1991; Troelstra et al., 1991], which was retrieved $500 \mathrm{~m}$ shallower in the northeastern part of the plain (Figure 1). The S1 sapropel is also present in this core at $30-44 \mathrm{~cm}$ (Figure 7), and like the cores in Figure 2, the $\mathrm{Sr} / \mathrm{Ca}$ profile exhibits values of $>0.005$ between 29 and $45 \mathrm{~cm}$ with a maximum value of 0.007 at $43 \mathrm{~cm}$. Chemical and XRD analyses of the Augias turbidite, which has $\mathrm{Sr} / \mathrm{Ca}$ values up to 0.018 , carried out in a similar manner to that applied to the core LC25 samples, yield a pure aragonite end-member with $10800 \mu \mathrm{g} \mathrm{Sr} \mathrm{g}^{-1}$ $\mathrm{CaCO}_{3}(\mathrm{Sr} / \mathrm{Ca}$ wt ratio $=0.027)$ and a zero aragonite endmember with $1680 \mu \mathrm{g} \mathrm{Sr} \mathrm{g}^{-1} \mathrm{CaCO}_{3}(\mathrm{Sr} / \mathrm{Ca}=0.0042$; 
Figure 6). The slight offset between the data from cores T87-19B and LC25 may be due to minor low-Sr pteropod aragonite that is present in core LC25 but absent in the Augias turbidite.

[26] The Augias turbidite data (Figure 6) prove that a source of algal high-Sr aragonite of a composition similar to that observed in the deepwater sediments studied exists in the shallow water sediments on the north African margin. Halimeda is abundant on many Mediterranean coasts and many coastal ridges of north Africa contain carbonate sands in which Halimeda is a major component [Burrolet et al., 1979] with resultant high aragonite and Sr contents [Holail, 1993]. The detrital hypothesis presented here envisages that monsoon floodwaters discharging from north Africa into the Mediterranean Sea entrain fine-grained shallow-water aragonite from the coastal photic zone and carry it into the surface waters of the basin, whence it would be removed in the settling flux to the sediments [Deuser et al., 1981, 1983]. In this case the linkage between $\mathrm{Sr} / \mathrm{Ca}$ and F. profunda must be through the volume of fresh water discharged from the continent, first in the amount of aragonite it can entrain and second in the subsequent degree of stratification it can produce. $\mathrm{The} \mathrm{Sr} / \mathrm{Ca}$ and $F$. profunda profiles through $\mathrm{S} 1$ might therefore be ascribed to a pulse of freshwater that rises to a maximum and then decreases during sapropel times, so that the volume of discharge flux controls both parameters. Halimeda is very productive, with estimates of annual production ranging between 300 and $3000 \mathrm{~g} \mathrm{CaCO}_{3} \mathrm{~m}^{-2} \mathrm{yr}^{-1}$ [Ballesteros, 1991; Freile et al., 1995], so that in principle it can rapidly rebuild its concentration in shallow photic zone sediments. This appears to be a viable explanation for the observed high$\mathrm{Sr}$ aragonite in sapropels.

\subsubsection{Aragonite Is Formed As a Consequence of} Sulphate Reduction During Sediment Diagenesis

[27] The third hypothesis is that the high-Sr aragonite in sapropel units is diagenetic, like the high-Mg calcite found in the marls. The characteristic difference between sapropel units and the enclosing marls is their high contents of preserved $\mathrm{C}_{\mathrm{org}}$ from primary production and of diagenetic $\mathrm{S}$ produced from $\mathrm{C}_{\text {org }}$ oxidation by $\mathrm{SO}_{4}^{2-}$ reduction. $\mathrm{C}_{\text {org }}$ remineralization affects sediment pore water alkalinity and hence the dissolution versus precipitation behavior of the sediment solid phase carbonates. Oxic remineralization of $\mathrm{C}_{\text {org }}$ produces $\mathrm{HCO}_{3}^{-}, \mathrm{HPO}_{4}^{2-}$, and $\mathrm{H}^{+}$and overall a net reduction in alkalinity. This leads to a lowering of the saturation state with respect to carbonate minerals in the sediment pore waters and induces dissolution of $\mathrm{CaCO}_{3}$, particularly of aragonite and high-Mg calcite in preference to calcite [Mucci et al., 2000; Green and Aller, 2001]. Such oxic remineralization occurs during formation of the $\mathrm{C}_{\text {org }}$-poor marls laid down between sapropel events [van Santvoort et al., 2002].

[28] Anoxic remineralization of $\mathrm{C}_{\text {org }}$ by $\mathrm{SO}_{4}^{2-}$ produces $\mathrm{HS}^{-}$along with $\mathrm{HCO}_{3}^{-}, \mathrm{HPO}_{4}^{2-}$, and $\mathrm{H}^{+}$, so there is a net increase in alkalinity, and the $\mathrm{H}^{+}$produced is consumed in the formation of FeS minerals if sufficient reactive $\mathrm{Fe}$ is available [Mucci et al., 2000]. Sulphate reduction therefore tends to induce $\mathrm{CaCO}_{3}$ precipitation rather than promote $\mathrm{CaCO}_{3}$ dissolution [Gaillard et al., 1989; Mucci et al.,
2000; Green and Aller, 2001]. While the oxygenation condition of bottom waters during formation of S1 is not well established [Casford et al., 2003], the presence of sulphides in and below S1 units demonstrates that anoxic conditions must have been established in pore waters at shallow depth very soon after sediment deposition [Passier et al., 1996].

[29] The sulphate reduction reaction may be summarized as

$$
2 \mathrm{CH}_{2} \mathrm{O}+\mathrm{SO}_{4}^{2-} \rightarrow 2 \mathrm{HCO}_{3}^{-}+\mathrm{H}_{2} \mathrm{~S},
$$

and the precipitation reaction as

$$
\mathrm{Ca}^{2+}+2 \mathrm{HCO}_{3}^{-} \rightarrow \mathrm{CaCO}_{3}+\mathrm{H}_{2} \mathrm{O}+\mathrm{CO}_{2} .
$$

[30] Reactions (1) and (2) are both usually bacterially mediated [Castanier et al., 1999], and Ehrlich [1996] reports that the precipitation of aragonite and other $\mathrm{CaCO}_{3}$ phases often accompanies the activities of sulphate-reducing bacteria. Each $1 \mathrm{wt} \%$ of diagenetic $\mathrm{S}$ formed is accompanied by sufficient $\mathrm{HCO}_{3}^{-}$from $\mathrm{C}_{\text {org }}$ to form $\sim 3 \mathrm{wt} \%$ $\mathrm{CaCO}_{3}$, so that the $3+$ wt $\% \mathrm{~S}$ in the core LC25 and $\mathrm{BC} 19$ sapropel samples with the largest $\mathrm{Sr} / \mathrm{Ca}$ ratios could produce $10 \%$ diagenetic $\mathrm{CaCO}_{3}$. This hypothesis leads to the expectation that the $\mathrm{Sr} / \mathrm{Ca}$ and diagenetic $\mathrm{S}$ profiles should be similar, with the additional $\mathrm{Sr}$ and $\mathrm{S}$ both sourced from bottom waters, and indeed the maximum levels of diagenetic $\mathrm{S}$ in sapropels always occur close to peak $\mathrm{Sr} / \mathrm{Ca}$ ratio values (Figure 3). The Sr data of cores LC25 and SL60 were therefore modeled (Figure 8) assuming three components implied by the systematics of Figures 5 and 6 , i.e., (1) $1 \mathrm{~mol}$ of aragonite with $\mathrm{Sr} / \mathrm{Ca}=0.027$ is produced along with each mole of diagenetic $\mathrm{S}$, (2) all remaining $\mathrm{Ca}$ present as $\mathrm{CaCO}_{3}$ with $\mathrm{Sr} / \mathrm{Ca}=0.0033$, and (3) detrital material with $\mathrm{Sr} / \mathrm{Al}=0.0137$. In order to reproduce a satisfactory fit, this calculation requires that all $\mathrm{S}$ produced from $\mathrm{SO}_{4}^{-}$by $\mathrm{C}_{\text {org }}$ remineralization is preserved in the sediments, whereas in fact much sulphide $\mathrm{S}$ undergoes reoxidation after formation [Boudreau et al., 1992]. Migration of sulfur and carbonate system species in the pore water solution is a further complication that is not taken into account. Although the calculation based on the stoichiometry of equations (1) and (2) therefore underestimates diagenetic Sr in cores LC25 and SL60, there are nevertheless similarities in the shape of the measured and modeled Sr profiles at around the correct level in the sapropel.

[31] It might be anticipated from the changes in pore water alkalinity that must occur during $\mathrm{C}_{\text {org }}$ remineralization that carbonate dissolution should occur between sapropel events under oligotrophic conditions with an oxic water column, while precipitation occurs in anoxic conditions during sapropel events. In fact, high contents of precipitated high-Mg calcite are also found in the marls deposited between sapropel events [Calvert and Fontugne, 2001] (Figure 4). This formation of high-Mg calcite has been ascribed to the high salinity of eastern Mediterranean bottom waters [Milliman and Müller, 1973], but the solubilities of aragonite and calcite both increase with increasing salinity [Mucci, 1983]. 

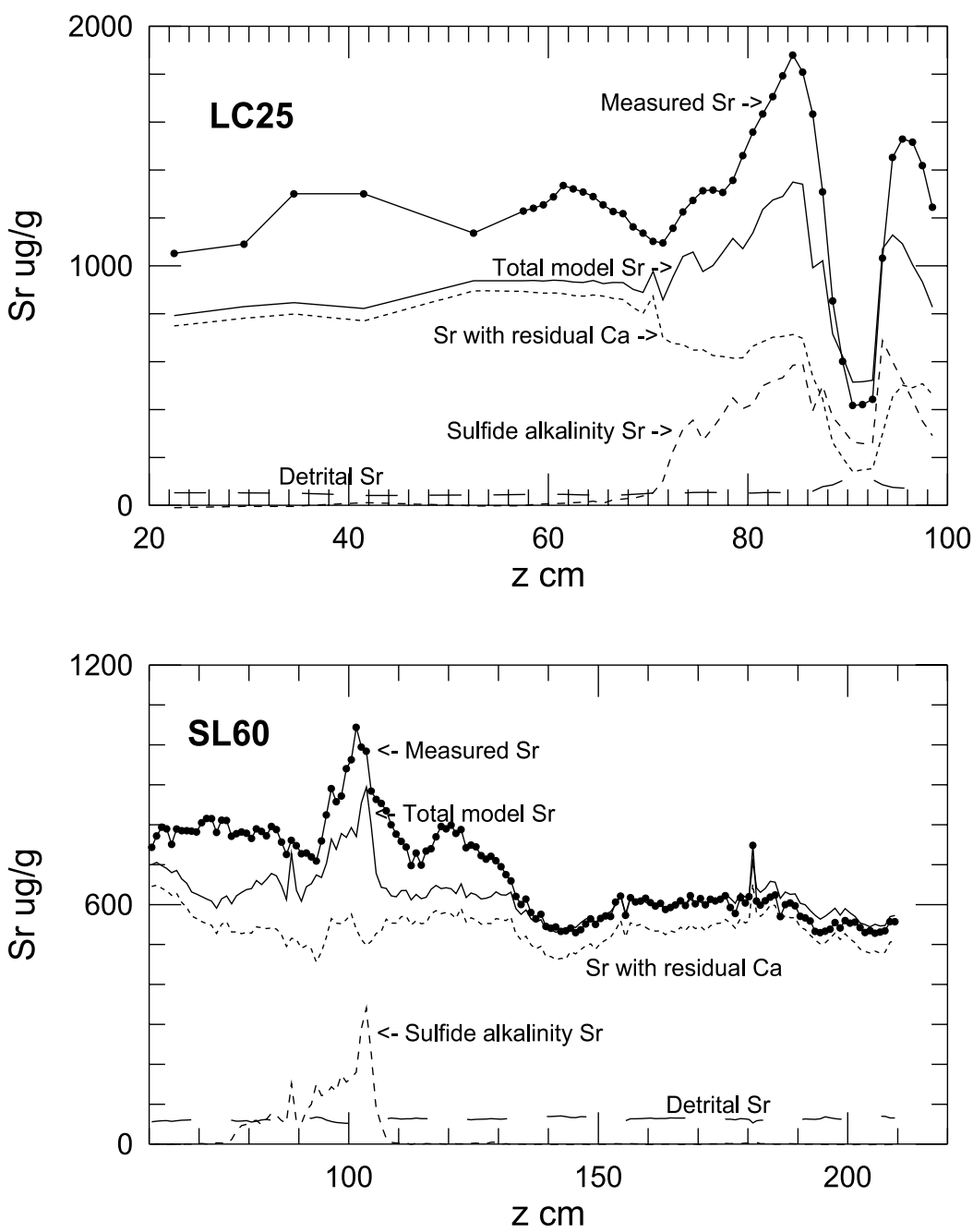

Figure 8. Model simulation of the total Sr in cores LC25 (upper) and SL60 (lower) versus depth compared with the measured $\mathrm{Sr}$ data. The total model assumes three components on the basis of the systematics of Figures 5 and 6. (1) $1 \mathrm{~mol}$ of aragonite with an $\mathrm{Sr} / \mathrm{Ca}$ content of 0.027 is produced along with each mole of $\mathrm{S}$, (2) all other $\mathrm{Ca}$ is present as $\mathrm{CaCO}_{3}$ with $\mathrm{Sr} / \mathrm{Ca}=0.0033$, (3) detrital material has $\mathrm{Sr} / \mathrm{Al}=0.0137$. This calculation requires that all $\mathrm{S}$ produced from $\mathrm{SO}_{4}^{2-}$ by $\mathrm{C}_{\text {org }}$ remineralization is preserved in the sediments, whereas some fraction may in fact be reoxidized.

If the high-Mg calcite and aragonite are diagenetic, the high $\mathrm{Mg}$ and $\mathrm{Sr}$ contents developed in them suggests that formation must occur early so that the necessary $\mathrm{Mg}$ and $\mathrm{Sr}$ can be supplied from bottom waters for incorporation into $\mathrm{CaCO}_{3}$. The $\mathrm{CaCO}_{3}$ polymorph that actually precipitates from a saturated pore water solution is a complex function of temperature and pore water composition [Burton and Walter, 1987; Burton, 1993]. At the seawater $\mathrm{Mg} / \mathrm{Ca}$ molar ratio of $5: 1$, aragonite is precipitated at temperatures $>6^{\circ} \mathrm{C}$, while calcites form at lower temperatures under similar conditions [Morse et al., 1997]. The well-mixed water column in the eastern Mediterranean basin everywhere has a temperature $>12.5^{\circ} \mathrm{C}$ [Klein et al., 1999], so that aragonite might be expected always to be the $\mathrm{CaCO}_{3}$ polymorph favored to precipitate in eastern Mediterranean sediments. The fact that high-Mg calcite is dominant outside sapropels (Figures 4 and 5) suggests that some critical local difference in pore water composition must dictate which $\mathrm{CaCO}_{3}$ polymorph forms, i.e., aragonite in and around sapropels but high- $\mathrm{Mg}$ calcite in the enclosing $\mathrm{C}_{\text {org }}$-poor marls. Some pore water species associated with sapropels or sulphide formation (e.g., $\mathrm{pH}$, dissolved organic matter, soluble reactive phosphate, or sulphide) may be involved, and pore water composition can suppress $\mathrm{CaCO}_{3}$ precipitation and allow oversaturation to reach high levels [Burton and Walter, 1987; Patterson and Walter, 1994].

[32] In summary, this diagenetic hypothesis is that $\mathrm{C}_{\text {org }}$ remineralized by $\mathrm{SO}_{4}^{2-}$ produced alkalinity that was precipitated to form aragonitic $\mathrm{CaCO}_{3}$ that incorporated $\mathrm{Sr}$ from the pore waters. Although the major difference between this and the production hypothesis is that the aragonite forms in the sediments rather than in the surface ocean, this mech- 
anism uncouples aragonite formation from $F$. profunda production.

\subsection{Florisphaera Profunda Abundance and Dissolution and Recrystallization in Biogenic Carbonates}

[33] The increases in the relative abundance of $F$. profunda observed in sapropels might be the result of a decrease in production of upper photic zone coccolithophores, and/or by an increase in $F$. profunda production in the lower photic zone, or by increased postdepositional dissolution of upper photic zone coccoliths in the sediments. In eastern Mediterranean sediments, Crudeli et al. [2004] have recognized both dissolution and overgrowth effects on coccoliths of Emiliania huxleyi, the most abundant coccolithophorid. Overgrowth effects were particularly marked in the marls above and below S1, corresponding to the levels where Calvert and Fontugne [2001] report high-Mg calcite (Figure 4). Well-preserved, heavily etched, and heavily overgrown E. huxleyi coccoliths could sometimes be identified in the same sample. It is not clear whether dissolution and precipitation occurred simultaneously in different microenvironments or in episodes at different times after deposition.

[34] Coccolithophore primary production changes are mainly influenced by nutrient availability and light [Brand, 1994], such that production occurs high in the photic zone when the nutricline is shallow and lower when the nutricline is deeper [Molfino and McIntyre, 1990a, 1990b; Castradori, 1993; Beaufort et al., 1997; Henriksson, 2000; de Garidel-Thoron et al., 2001]. Gladiolithus flabellatus and Algirosphaera robusta dominate the modern nannoflora assemblage at $>100 \mathrm{~m}$ in the Mediterranean Sea along with F. profunda [Knappertsbusch, 1993; Ziveri et al., 2000; Cros, 2002]. Although simultaneous production of all three species is expected [Broerse et al., 2000; Takahashi and Okada, 2000], G. flabellatus and A. robusta are rarely reported from the fossil record. Instead, F. profunda is often the only lower photic zone species preserved in deepwater sediments because it is the most solution-resistant species of the three [Matsuoka and Okada, 1989; Okada and Matsuoka, 1996; Okada and Wells, 1997; Takahashi and Okada, 2000; Okada, 2000]. The patterns of G. flabellatus and A. robusta were therefore compared with those of F. profunda in order to evaluate whether coccolithophore dissolution might affect abundance patterns.

[35] G. flabellatus and A. robusta are at much lower abundance, and their profiles are quite different in shape from those of F. profunda in cores BC19, SL114, and SL60 (Figure 9). In cores BC19 and SL114, both species are variably present both above and below sapropel S1 but are at low abundance or completely absent within the sapropel itself. In contrast, both species are continuously present and relatively abundant through the sapropel in core SL60 where the sediments are more rapidly accumulated (Figure 9). Crudeli and Young [2003] observed by SEM that single lamellar fragments and broken coccoliths of A. robusta were abundant in sapropel S1 sediments, but such small lamellar fragments are not detected by LM, and consequently the number of $A$. robusta coccoliths is underestimated. Whereas G. flabellatus has been reported

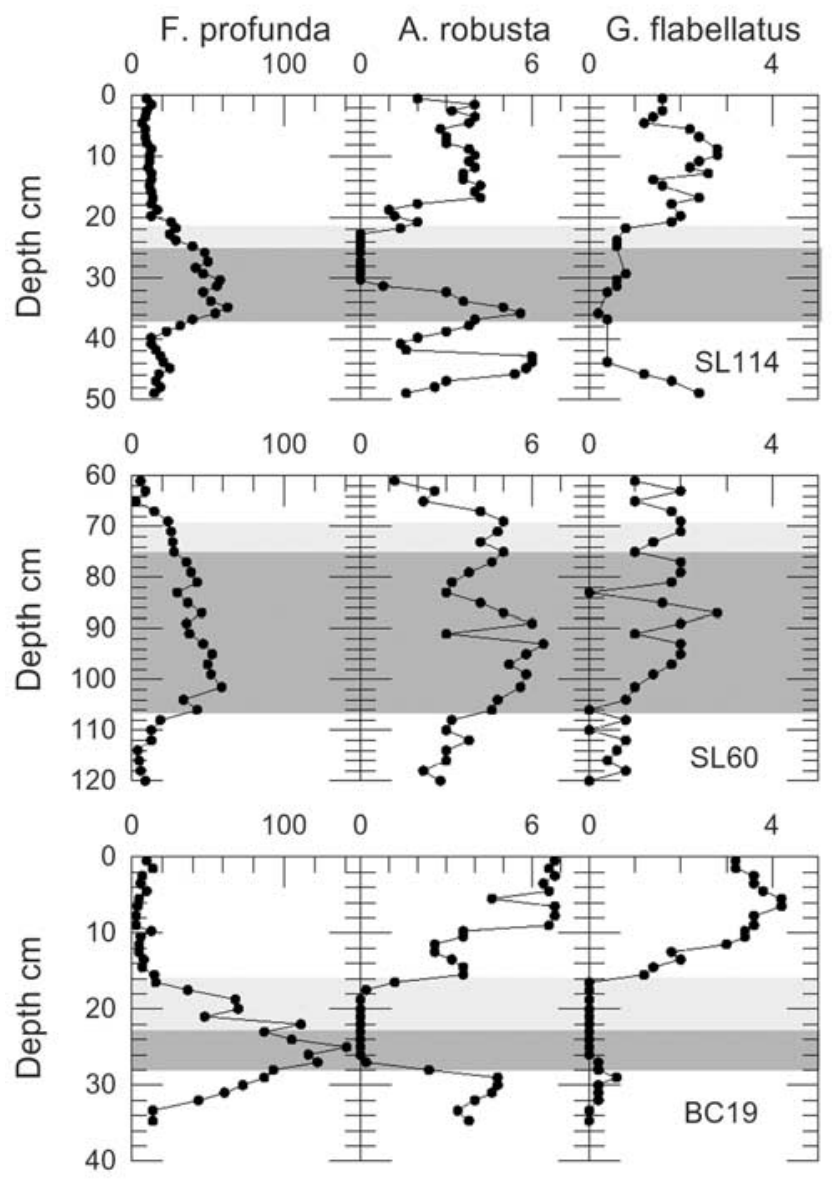

Figure 9. Downcore profiles of Florisphaera profunda, Algirosphaera robusta, and Gladiolithus flabellatus in cores SL114 (upper panels), SL60 (middle panels), and BC19 (lower panels). Light and dark shading indicate the oxidized and unoxidized parts of the S1 sapropels.

to have a depth preference closely similar to that of $F$. profunda, A. robusta has a somewhat wider depth distribution and has also been reported from the middle photic zone [Jordan and Winter, 2000; Cros, 2002]. While the marked decrease of $A$. robusta in sapropel S1 in cores SL114 and BC19 might therefore be ascribed to some unfavorable condition occurring higher in the photic zone during sapropel deposition, the absence of $G$. flabellatus in the presence of $F$. profunda is more difficult to explain on the basis of the known ecological preferences of the two species. It is therefore suspected that the different trends of $G$. flabellatus and A. robusta by comparison with F. profunda in cores BC19 and SL114 are related to their dissolution and fragmentation in the water column or sediments rather than to environmental conditions. This selective dissolution hypothesis is supported by the presence of etched and broken E. huxleyi coccoliths in sapropel S1 [Crudeli et al., 2004] and by the dominance of structurally solid holococcoliths over more delicate forms [Crudeli and Young, 2003]. Moderately overgrown coccoliths of E. huxleyi were also found in the S1 sapropel 
sediments of core SL60, whereas such forms are completely absent in the sapropels of cores SL114 and BC19 [Crudeli et al., 2004]. This may imply that early diagenetic carbonate precipitation has allowed a better preservation of the delicate G. flabellatus and A. robusta forms in core SL60, and their slight increase in abundance within $\mathrm{S} 1$ in this core supports the idea of proliferation of both species during sapropel deposition.

[36] It is important to note that overall dissolution of the carbonate nannoflora within sapropel S1 is of moderate intensity in all these cores since some very delicate forms are still present [Crudeli and Young, 2003]. G. flabellatus and $A$. robusta were quantified independently of $F$. profunda platelets, and their abundance patterns do not affect the corresponding $F$. profunda profiles. Nevertheless, the G. flabellatus and A. robusta trends are probably evidence that species-selective carbonate dissolution is or has been active in these sediments, and it is possible that dissolution of other coccoliths has affected $F$. profunda profiles to some extent in cores SL114 and BC19 at least.

\subsection{Aragonite Morphology and Composition by Scanning Electron Microscopy and Ion Probe}

[37] It was hoped that a choice between the alternatives for the high-Sr aragonite formation might be assisted by SEM and Ion Probe studies, but recrystallization effects complicate the recognition and differentiation of biogenic and diagenetic aragonite. Aragonite and Mg-calcite dissolution and recrystallization are both widespread during very early diagenesis in shallow water carbonates [Macintyre and Reid, 1995; Reid and Macintyre, 1998; Hover et al., 2001]. Substrate control often appears to favor isomorphic recrystallization, and Hover et al. [2001] concluded that the driving force in recrystallization was a minimization of crystal surface free energy through an increase in crystal size. In the case of eastern Mediterranean sediments, however, the E. huxleyi dissolution observed by Crudeli et al. [2004], and the likely dissolution of other species discussed above is evidence that some dissolution of the less soluble biogenic low-Mg calcite must be occurring, or have occurred, in these sediments, despite the presence of the more soluble high-Mg calcite and aragonite forms (Figures 4 and 6).

[38] In samples from the S1 sapropel in cores LC25 and T87-19B, the dominant forms identified on morphological grounds as aragonite by SEM were aggregates of needles or "rods," typically $1-5 \times \sim 0.2 \mu \mathrm{m}$ in dimension and very small $(0.5 \mu \mathrm{m})$ equant crystals (Figure 10). Ion microprobe determination of $\mathrm{Sr}$ and $\mathrm{Ca}$ in particles on stubs that had also been examined by SEM confirmed that all biogenic nannoplankton consistently analyzed with a $\mathrm{Sr} / \mathrm{Ca}$ mass ratio in the range $0.001-0.003$, whereas the rod aggregates had $\mathrm{Sr} / \mathrm{Ca}$ mass ratios in the range $0.02-0.03$.

[39] Both well-separated and more fused rods were observed in the different aggregates (Figures 10a-10d and 10f). In those aggregates with a loose open framework of randomly oriented rods, the rods commonly had smooth surfaces and rounded terminations (Figures 10a and 10b) and resembled the original aragonitic skeletal needles of the calcareous alga Halimeda reported by Macintyre and Reid [1995, Figures $2 \mathrm{~b}$ and 2c]. The thicker rods in these aggregates did not, however, exhibit the blunt crystal terminations and well-developed crystal faces typical of needles of living Halimeda [Hover et al., 2001, Figure 6c]. The second type of aggregate, in which the rod framework appears more fused, is more common (Figures 10c and 10d), and in this type the rods have more irregular surfaces, rounded terminations, and some cementation between them. The surfaces of these rods appear better preserved than the etched surface of bioneedles illustrated by Macintyre and Reid [1995, Figure 7b]. Morphologically, these rods resemble etched aragonitic needles from carbonate platforms reported by Melim et al. [2002, Plate II, Figure c]. A third type of aggregate with a loose framework, characterized by well-spaced elongate crystals (typically 1-5 m long $\times 0.07 \mathrm{~m}$ thick) was also observed. This form was commonly surrounded by what appeared to be amorphous organic matter (Figure 10f), and the crystals vaguely resemble the inorganic precipitates reported by Robbins and Blackwelder [1992, Figure 3b] and aragonitic needles from living calcareous algae [Reid and Macintyre, 1998, Figure 1e]. In addition to aggregates, randomly spaced single rods were also common, and subcircular anhedral microcrystals $(0.5 \mathrm{~m})$ were occasionally present (Figure 10e) that are similar to the nanograins produced by progressive micritization of original skeletal needles documented by Macintyre and Reid [1995, Figures 3c, 3e, 6b, 6e] and to the crystal form of many calcareous algae [Macintyre and Reid, 1992, Figure 2].

[40] The sapropel S1 aggregates are typically smaller (rarely $>20 \mu \mathrm{m}$ with an average of all types of $\sim 8 \mu \mathrm{m}$ ) and more irregular in shape than those from the Augias turbidite (Figures $10 \mathrm{~g}$ and $10 \mathrm{~h}$ ) that were referred to Halimeda sp. by Hieke and Werner [2000]. Some larger aggregates were subcircular to elliptical in shape, $5-10 \mathrm{~m}$ in length (Figure $10 \mathrm{~g}$ ), and resembled faecal pellets [e.g., Wassmann et al., 2000]. Although the individual needles comprising the different aggregates appear similar, the degree of compaction and fusion always appears less in the sapropel S1 aggregates than in the Augias turbidite grain illustrated by Hieke and Werner [2000, Figure 2].

[41] The irregular rod surfaces and cements might indicate recrystallization of original aragonite needles (J. Reijmer, personal communication, 2003), and the predominantly needle- or rod-like morphology might suggest a biogenic origin of these aggregate structures. Since etching and progressive micritization have been shown to alter original aragonitic needle morphology dramatically, however [Macintyre and Reid, 1995; Hover et al., 2001], postdepositional alteration of the original morphology is also possible.

[42] A few irregular small particles with much higher $\mathrm{Sr} / \mathrm{Ca}$ mass ratios in the range $0.12-0.15$ were also observed in ion microprobe analysis (Figure 10i), and the fact that one of these particles appears to have grown around a Syracosphaera coccolith (Figure 10j) suggests that they are likely to be diagenetic. While it was not possible to identify the nature of these high Sr particles further, their occasional presence may contribute to the aragonite endmember that has a $\mathrm{Sr} / \mathrm{Ca}$ mass ratio higher than that anticipated for biogenic aragonite (Figure 6). Rare examples of distinctive aragonitic didemnid ascidians with sparse 

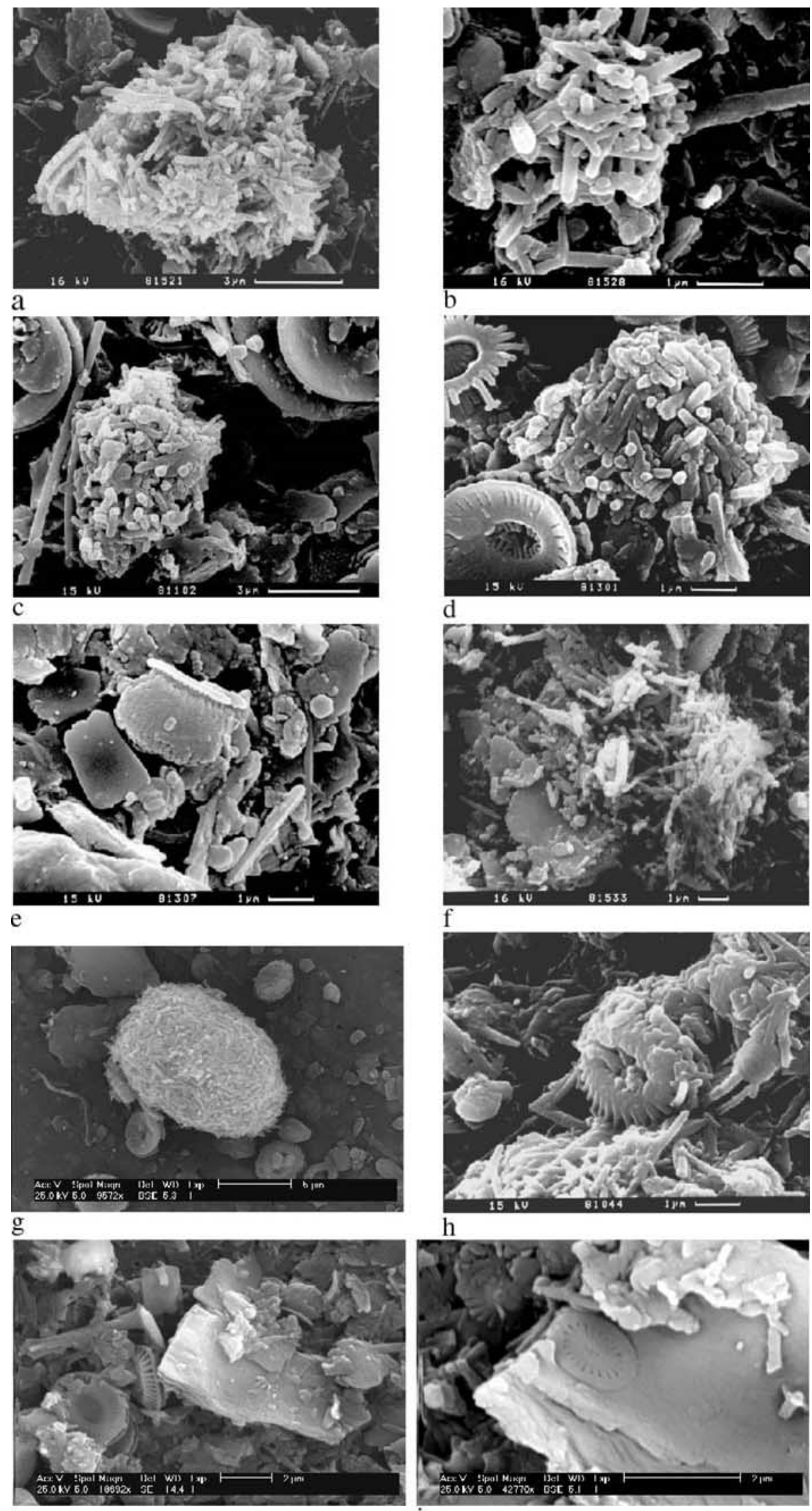

Figure 10 
aragonite needle overgrowths were observed (not shown), and these are likely to have been sourced from shallow waters [Varol and Houghton, 1996]. Ion probe determinations of these didemnid ascidians indicated $\mathrm{Sr} / \mathrm{Ca}$ mass ratios in the range $0.02-0.03$, similar to the aragonite rods.

\subsection{Preferred Mechanism for Aragonite in Sapropels and Implications for the Evolution of Sapropel Formation Episodes}

[43] The difficulties experienced in ascribing genesis to the aragonite morphologies observed by SEM do not allow an unequivocal selection between the three alternatives of aragonite supply discussed above. No evidence was found for any high Sr biogenic forms that would match the production mechanism, however, and although the detrital hypothesis cannot be discounted, the diagenetic explanation appears the most likely. The reasons for this are the observed alternation of aragonite with diagenetic high-Mg calcite (Figures 4 and 5), the indicated high Sr end-member contents that exceed biogenic high-Sr aragonite and resemble those of aragonitic cements (Figure 6), and the co-occurrence of highest $\mathrm{Sr} / \mathrm{Ca}$ ratios with high $\mathrm{S}$ contents because of the inescapable alkalinity increases that accompany sulfate reduction (Figure 3). Diagenetic carbonate formation is so widespread in eastern Mediterranean sediments that hardgrounds, generally composed of high-Mg calcite, are sometimes formed at the sediment surface [Allouc, 1990]. Hardgrounds with a different genesis have also been reported at and just under the sediment water interface at cold seep sites in the eastern Medoterranean basin [Aloisi et al., 2000, 2002]. In cold seep examples, methane oxidation and sulphate reduction are both active at shallow depth in the sediments, so that an increase in pore water alkalinity accompanies methane oxidation by sulfate [Lein et al., 2002]:

$$
\mathrm{CH}_{4}+\mathrm{SO}_{4}^{2-} \rightarrow \mathrm{HCO}_{3}^{-}+\mathrm{HS}^{-}+\mathrm{H}_{2} \mathrm{O} .
$$

[44] Aloisi et al. [2002] ascribed an observed alternation of aragonite at the surface and high-Mg calcite at greater depth in cold seep crusts to an inhibition of high-Mg calcite precipitation by pore water sulfate, with aragonite formed at higher pore water sulphate levels and high-Mg calcite formed where pore water sulfate was depleted. Such an explanation will not serve for the sediment observations here of preferential high-Mg calcite formation in the marls and aragonite formation in the sapropels. It is clear that the diagenetic precipitation of either high- $\mathrm{Mg}$ calcite or aragonite must be in delicate balance in eastern Mediterranean sediments, and the alternations observed in the sediments here and in the cold seep hardgrounds could both be explained by a preferential formation of aragonite along with sulfate reduction, possibly by sulfate reducing bacteria.

[45] If the alkalinity generated with sulphide formation is the source for the formation of diagenetic aragonite in sapropels, then formation of aragonite and the proliferation of $F$. profunda must be indirectly related. From studies of laminated sapropel intervals, Kemp et al. [2000] have suggested that the autumn pulse of diatom production in the DCM represents an important fraction of total annual production. Although this could lead to the speculation that F. profunda might be a useful indicator for overall (as opposed to just DCM) production during sapropel formation, the differences in the F. profunda and $\mathrm{Ba} / \mathrm{Al}$ (as an indicator of the original $\mathrm{C}_{\text {org }}$ profiles in the $\mathrm{S} 1$ units) profiles clearly suggest rather different production patterns through time.

[46] S1 formation is usually equated with the Holocene African Humid Period [e.g., Rossignol-Strick, 1999; Gasse, 2002]. Application of Castradori's [1993] concept to the F. profunda profiles through S1 implies that the DCM component of total upper ocean production and hence monsoon outflow from the continents were at a maximum early in S1 times. F. profunda values begin to increase from low (baseline) values at $\sim 11{ }^{14} \mathrm{C}$ kyr B.P., peak around $9{ }^{14} \mathrm{C}$ kyr B.P., and subsequently decline toward baseline until $5{ }^{14} \mathrm{C}$ kyr B.P. (Figure 3). In contrast, the increased $\mathrm{C}_{\text {org }}$ contents and high $\mathrm{Ba} / \mathrm{Al}$ ratio values used to indicate sapropel thickness do not increase above their low baseline

\footnotetext{
Figure 10. SEM images of forms interpreted as aragonite in sapropel S1 and Augias Turbidite sediments, illustrating the variations in size and cementation/compaction of rod aggregates. (a) Aggregate of loosely compacted rods, most of which are $>1 \mu \mathrm{m}$ in length. Micritization appears less pervasive in this example than in those of Figures $1 \mathrm{c}$ and $10 \mathrm{~d}$, although the rods in the lower center of this aggregate appear more cemented. The surfaces of single rods are less irregular than those in Figures 10c and 10d (S1 sapropel at $83 \mathrm{~cm}$ in section 10 in core LC25). (b) Small aggregate of rods in a loose framework ( $\mathrm{S} 1$ sapropel at $83 \mathrm{~cm}$ in section 10 in core LC25). (c) Aggregate of compacted rods. Here most rods are $\sim 1 \mu \mathrm{m}$ long, and their surfaces are irregular as if etched. (S1 sapropel at $43 \mathrm{~cm}$ in core T87-19B.) (d) Aggregate of compacted rods in which most rods are slightly longer than those in Figure 10c but have the same irregular surface. There are distal views of etched E. huxleyi coccoliths to the upper right and upper left, and a proximal view of a well-preserved E. huxleyi to the bottom left ( $\mathrm{S} 1$ sapropel at $43 \mathrm{~cm}$ in core T87-19B). (e) Well-preserved coccoliths of A. robusta (center) and F. profunda (immediately left of center). There is a subrounded aragonite(?) nanograin $(0.5 \mu \mathrm{m}$ in diameter) three quarters way up the frame on the right hand side (S1 sapropel at $43 \mathrm{~cm}$ in core T87-19B). (f) Loose aggregate of very thin rods mostly $>1 \mu \mathrm{m}$ long. Organic matter(?) obscures thin rods at the lower right side of the image (S1 sapropel at $83 \mathrm{~cm}$ in section 10 in core LC25). (g) Aggregate of closely spaced, medium-sized rods with a faecal pellet-like morphology (Augias Turbidite at $12 \mathrm{~cm}$ in core T87-19B). (h) Aragonite rods surrounding a coccolith of E. huxleyi that shows etching on the elements of the distal shield (Augias Turbidite at $12 \mathrm{~cm}$ in core T87-19B). (i) Unidentified particle with extremely high $\mathrm{Sr} / \mathrm{Ca}$ values (center) with a F. profunda platelet at the upper left (S1 sapropel at $83 \mathrm{~cm}$ in section 10 in core LC25). (j) Magnification of a particle with a high $\mathrm{Sr} / \mathrm{Ca}$ ratio showing inclusion of a small Syracosphaera coccolith that indicates a probable later diagenetic origin for this particle ( $\mathrm{S} 1$ sapropel at $83 \mathrm{~cm}$ in section 10 in core LC25).
} 
values until after $10{ }^{14} \mathrm{C}$ kyr B.P., rise sharply between 10 and $9{ }^{14} \mathrm{C}$ kyr B.P., maintain consistently high levels between 9 and $6.5{ }^{14} \mathrm{C}$ kyr B.P., and then fall off between 6.5 and $6{ }^{14} \mathrm{C}$ kyr B.P. These differences between the F. profunda and $\mathrm{Ba} / \mathrm{Al}$ profiles suggest that production in the surface ocean must increase well before sapropel formation begins in the sediments. In turn, this suggests that development of anoxia/dysoxia between 11 and $10{ }^{14} \mathrm{C}$ kyr B.P. in a stabilized, poorly ventilated deeper water column was necessary before high $\mathrm{C}_{\text {org }}$ contents could begin to be preserved in the sediments to form sapropel. Consistently high values of $\mathrm{C}_{\text {org }}$ and $\mathrm{Ba} / \mathrm{Al}$ were then maintained in the sediments deposited between 9 and $6.5 \mathrm{kyr}$, whereas the $F$. profunda profiles suggest that at least the DCM component of total production was continuously decreasing between 9 and $5{ }^{14} \mathrm{C}$ kyr B.P. The return of $\mathrm{Ba} / \mathrm{Al}$ to its baseline values at $6{ }^{14} \mathrm{C} \mathrm{kyr}$ B.P. also occurs before $F$. profunda returns to its baseline at $5{ }^{14} \mathrm{C}$ kyr B.P. (Figure 3). In reverse of the scenario to initiate sapropel development, this suggests that water column stabilization must have broken down and good ventilation must have resumed to reoxygenate deep water after $6.5{ }^{14} \mathrm{C}$ kyr. Thus sapropel formation terminated after $6{ }^{14} \mathrm{C}$ kyr B.P., even though surface ocean production did not return to the low levels of $F$. profunda that typify nonsapropel times until $5{ }^{14} \mathrm{C}$ kyr B.P.

\section{Conclusions}

[47] Unlike most other deepwater marine sediments, eastern Mediterranean basin sediments contain both the more soluble $\mathrm{CaCO}_{3}$ forms aragonite and high-Mg calcite, predominantly in sapropels and in the intercalated marls, respectively. The repeated finding of maxima in the
F. profunda index and $\mathrm{Sr} / \mathrm{Ca}$ ratio profiles around the same depths in the most recent sapropel was unexpected because F. profunda, other biogenic calcite, and pteropod aragonite cannot be the source of the observed high-Sr aragonite. Although the aragonite could have been formed or emplaced by other mechanisms, the alkalinity generated by sulphate reduction appears to be the likely principal source for the formation and recrystallization of aragonite in and around sapropels.

[48] Similar high $\mathrm{Sr} / \mathrm{Ca}$ ratios and inferred aragonite formation also occur at, or immediately below, the bases of the last few eastern Mediterranean sapropels, suggesting that aragonite generally accompanies sapropel formation in this basin. Regardless of the mechanism of formation of high-Sr aragonite, the $F$. profunda maxima and $\delta^{18} \mathrm{O}$ monsoon rainfall minima always occur very early in the episodes when high $\mathrm{C}_{\text {org }}$ contents are preserved as sapropels in the sediments along with highest diagenetic sulfide contents. In the case of sapropel S1 the development of the production pulse in the upper water column that is signaled by $F$. profunda clearly begins earlier and finishes later than the resultant formation of sapropel in the sediments.

[49] Acknowledgments. This work was partly supported by the EU Marine Science and Technology Framework V project Sapropels and Paleoceanography (MAS3-CT97-0137) and the Natural Sciences and Engineering Research Council of Canada (SEC). We are grateful to Trevor Clayton of SOC for XRD analyses, to Simon Troelstra of The Free University, Amsterdam, for the core T87-19B samples, to Guy Rothwell of the British Ocean Sediment Core Research Facility at SOC for the core LC25 samples, to Ute Schuldt and the Ocean Gateways Research Unit at Kiel University for assistance with and support of the SEM analyses, and to John Reimer of IFM-GEOMAR for discussions on the aragonite aggregates. Constructive referee comments from T. Lyons and H. Stoll on the original manuscript greatly improved this version.

\section{References}

Aksu, A. E., D. Yasar, and P. J. Mudie (1995), Origin of late glacial-Holocene hemipelagic sediments in the Aegean Sea: Clay mineralogy and carbonate cementation, Mar. Geol., 123, $33-59$.

Allouc, J. (1990), Quaternary crusts on slopes of the Mediterranean Sea-A tentative explanation for their genesis, Mar. Geol., 94, 205238.

Aloisi, G., C. Pierre, J. M. Rouchy, J. P. Foucher, and J. Woodside (2000), Methane-related authigenic carbonates of eastern Mediterranean Sea mud volcanoes and their possible relation to gas hydrate destabilisation, Earth Planet. Sci. Lett., 184, 321-338.

Aloisi, G., I. Bouloubassi, S. K. Heijs, R. D. Pancost, C. Pierre, J. S. S. Damste, J. C. Gottschal, L. J. Forney, and J. M. Rouchy (2002), $\mathrm{CH}_{4}$-Consuming microorganisms and the formation of carbonate crusts at cold seeps, Earth Planet. Sci. Lett., 203, 195203.

Andruleit, H. (1996), A filtration technique for quantitative studies of coccoliths, Micropaleontology, 42, 403-406.

Ballesteros, E. (1991), Seasonality of growth and production of a deep-water population of Halimeda tuna (Chlorophyceae, Caulerpales) in the northwestern Mediterranean, Bot. Mar, 34, 291-301.

Bard, E., G. Delaygue, F. Rostek, F. Antonioli, S. Silenzi, and D. P. Schrag (2002), Hydrological conditions over the western Mediterranean basin during the deposition of the cold Sapropel 6 (ca. 175 kyr BP), Earth Planet. Sci. Lett., 202, 481-494

Barkan, E., B. Luz, and B. Lazar (2001), Dynamics of the carbon dioxide system in the Dead Sea, Geochim. Cosmochim. Acta, 65, 355-368.

Bar-Matthews, M., A. Ayalon, and A. Kaufman (2000), Timing and hydrological conditions of sapropel events in the eastern Mediterranean, as evident from speleothems, Soreq cave, Israel, Chem. Geol., 169, 145156.

Beaufort, L., Y. Lancelot, P. Camberlin, O .Cayre, E. Vincent, F. Bassinot, and L. Labeyrie (1997), Insolation cycles as a major control of equatorial Indian Ocean primary production, Science, 278, 1451-1454.

Beck, J. W., R. L. Edwards, E. Ito, F. W. Taylor, J. Recy, F. Rougerie, P. Joannot, and C. Henin (1992), Sea-surface temperature from coral skeletal strontium calcium ratios, Science, $257,644-647$.
Berner, R. A., and S. Honjo (1981), Pelagic sedimentation of aragonite: Its geochemical significance, Science, 211, 940-942.

Bernstein, R. E., R. H. Byrne, P. R. Betzer, and A. M. Greco (1992), Morphologies and transformations of celestite in seawater: The role of acantharians in strontium and barium geochemistry, Geochim. Cosmochim. Acta, 563 273-3279.

Bernstein, R. E., R. H. Byrne, and J. Schijf (1998), Acantharians: A missing link in the oceanic biogeochemistry of barium, Deep Sea Res. Part I, 45, 491-505.

Bertram, M. A., and J. P. Cowen (1997), Morphological and compositional evidence for biotic precipitation of marine barite, J. Mar. Res., 55, 577-593.

Boss, S. K., and A. C. Neumann (1993), Physical versus chemical processes of whiting formation in the Bahamas, Carbonate Evaporite, $81,35-148$.

Boudreau, B. P., D. E. Canfield, and A. Mucci (1992), Early diagenesis in a marine sapropel, Mangrove Lake, Bermuda, Limnol. Oceanogr. $371,738-1753$.

Brand, L. E. (1994), Physiological ecology of marine phytoplankton in coccolithophores, in Coccolithophores, edited by A. Winter and 
W. G. Siesser, pp. 39-49, Cambridge Univ. Press, New York.

Broecker, W. S., A. Sanyal, and T. Takahashi (2000), The origin of Bahamian whitings revisited, Geophys. Res. Lett., 27, 3759-3760.

Broecker, W. S., C. Langdon, and T. Takahashi (2001), Factors controlling the rate of $\mathrm{CaCO}_{3}$ precipitation on great Bahama Bank, Global Biogeochem. Cycles, 15, 589-596.

Broerse, A. T. C., P. Ziveri, J. E. van Hinte, and S. Honjo (2000), Coccolithophore export production, species composition and coccolith$\mathrm{CaCO} 3$ fluxes in the NE Atlantic $\left(34^{\circ} \mathrm{N}\right.$ $21^{\circ} \mathrm{W}$ and $\left.48^{\circ} \mathrm{N} 21^{\circ} \mathrm{W}\right)$, Deep Sea Res. Part II, 47, 1877-1905.

Burrolet, P. F., M. Cassoudebat, and F. Duval (1979), La Mer Pélagienne-IV Les constituants lithologiques A-Microfaciés, Geol. Mediter., $83-110$.

Burton, E. A. (1993), Controls on marine carbonate cement mineralogy - Review and reassessment, Chem. Geol., 105, 163-179.

Burton, E. A., and L. M. Walter (1987), Relative precipitation rates of aragonite and $\mathrm{Mg}$ calcite from seawater: Temperature or carbonate ion control?, Geology, 15, 111-114.

Calvert, S. E. (1983), Geochemistry of Pleistocene sapropels and associated sediments from the eastern Mediterranean, Oceanol. Acta, 6, 255-267.

Calvert, S. E., and M. R. Fontugne (2001), On the late Pleistocene-Holocene sapropel record of climatic and oceanographic variability in the eastern Mediterranean, Paleoceanography, 16, $78-94$.

Casford, J. S. L., E. J. Rohling, R. H. Abu-Zied, C. Fontanier, F. J. Jorissen, M. J. Leng, G. Schmiedl, and J. Thomson (2003), A dynamic concept for eastern Mediterranean circulation and oxygenation during sapropel formation, Palaeogeogr. Palaeoclimatol. Palaeoecol., 190, 103-119.

Castanier, S., G. Le Métayer-Levrel, and J.-P. Perthuisot (1999), Ca-carbonates precipitation and limestone genesis-The microbiologist point of view, Sediment. Geol., 126, 9-23.

Castradori, D. (1993), Calcareous nannofossils and the origin of eastern Mediterranean sapropels, Paleoceanography, 8, 459-471.

Castradori, D. (1998), Calcareous nannofossils in the basal Zanclean of the eastern Mediterranean Sea: Remarks on paleoceanography and sapropel formation, Proc. Ocean Drill. Program, Sci. Results, 160, 113-123.

Cita, M. B., and G. Aloisi (2000), Deep-sea tsunami deposits triggered by the explosion of Santorini (3500 y BP), eastern Mediterranean, Sediment. Geol., 135, 181-203.

Corselli, C., M. S. Principato, P. Maffioli, and D. Crudeli (2002), Changes in planktonic assemblages during sapropel S5 deposition: Evidence from Urania Basin area, eastern Mediterranean, Paleoceanography, 17(3), 1029, doi:10.1029/2000PA000536.

Cros, M. L. (2002), Planktonic coccolithophores of the NW Mediterranean, 181 pp., Univ. Barcelona, Barcelona.

Crudeli, D., and J. R. Young (2003), SEM-LM study of holococcoliths preserved in eastern Mediterranean sediments (Holocene/late Pleistocene), J. Nannoplankton Res., 25, 3950.

Crudeli, D., J. R. Young, E. Erba, G. J. de Lange, K. Henriksen, H. Kinkel, C. P. Slomp, and P. Ziveri (2004), Abnormal carbonate diagenesis in Holocene-late Pleistocene sapropel-associated sediments from the eastern Mediterranean: Evidence from Emilia- nia huxleyi coccolith morphology, Mar. Micropaleontol, in press.

de Garidel-Thoron, T., L. Beaufort, B. K. Linsley, and S. Dannenmann (2001), Millennial-scale dynamics of the east Asian winter monsoon during the last 200,000 years, Paleoceanography, 16, 491-502.

Dehairs, R., R. Chesselet, and J. Jedwab (1980), Discrete suspended particles of barite and the barium cycle in the open ocean, Earth Planet Sci. Lett., 49, 529-550.

Delaney, M. L., L. J. Linn, and P. J. Davies (1996), Trace and minor element ratios in Halimeda aragonite from the Great Barrier Reef, Coral Reefs, 15, 181-189.

Deuser, W. G., E. H. Ross, and R. F. Anderson (1981), Seasonality in the supply of sediment to the deep Sargasso Sea and implications for the rapid transfer of matter to the deep ocean, Deep Sea Res., 28, 495-505.

Deuser, W. G., P. G. Brewer, T. D. Jickells, and R. F. Commeau (1983), Biological control of the removal of abiogenic particles from the surface ocean, Science, 219, 388-391.

Dittrich, M., P. Kurz, and B. Wehrli (2004), The role of autotrophic picocyanobacteria in calcite precipitation in an oligotrophic lake, Geomicrobiol. J., 21, 45-53.

Ehrlich, H. L. (1996), Geomicrobiology, 3rd ed., Marcel Dekker, New York.

Fabry, V. J., and W. G. Deuser (1991), Aragonite and magnesian calcite fluxes to the deep Sargasso Sea, Deep Sea Res. Part I, 38, 713-728.

Freile, D., J. D. Milliman, and L. Hillis (1995), Leeward bank margin Halimeda meadows and draperies and their sedimentary importance on the Great Bahama Bank slope, Coral Reefs, $14,27-33$.

Friedman, G. M. (1965), Occurrence and stability relationships of aragonite, high-magnesian calcite and low-magnesian calcite under deepea conditions, Geol. Soc. Am. Bull., 76, $1191-1196$

Friedman, G. M. (1993), Biochemical and ultrastructural evidence for the origin of whitingsA biologically induced calcium carbonate precipitation mechanism, Comment, Geology, 21 , $287-288$.

Friedman, G. M. (1994), Great Bahama Bank aragonitic muds, mostly inorganically precipitated, mostly exported-Discussion, J. Sediment. Res., 64, 921-922.

Gaillard, J.-F., H. Pauwels, and G. Michard (1989), Chemical diagenesis in coastal marine sediments, Oceanol. Acta, 12, 175-187.

Gasse, F. (2002), Diatom-inferred salinity and carbonate oxygen isotopes in Holocene waterbodies of the western Sahara and Sahel (Africa), Quat. Sci. Rev., 21, 737-767.

Green, M. A., and R. C. Aller (2001), Early diagenesis of calcium carbonate in Lon Island Sound sediments: Benthic fluxes of $\mathrm{Ca}$ and minor elements during seasonal periods of net dissolution, J. Mar. Res., 59, $769-794$.

Henriksson, A. S. (2000), Coccolithophores response to oceanographic changes in the equatorial Atlantic during the last 200,000 years, Palaeogeogr. Palaeoclimatol. Palaeoecol., 156, 161-173.

Hieke, W., and F. Werner (2000), The Augias megaturbidite in the central Ionian Sea (centra Mediterranean) and its relation to the Holocene Santorini event, Sediment. Geol., 135, 205 218

Higgs, N. C., J. Thomson, T. R. S. Wilson, and I. W. Croudace (1994), Modification and complete removal of eastern Mediterranean sapropels by postdepositional oxidation, Geology, 22, 423-426.

Hilgen, F. J. (1991), Astronomical calibration of Gauss to Matuyama sapropels in the Mediterranean and implication for the geomagnetic polarity time scale, Earth Planet. Sci. Lett., 104, 226-244.

Holail, H. (1993), Diagenetic trends of the Pleistocene calcareous ridges, Marsa Matruh area, Egypt, Chem. Geol., 106, 375-388

Hover, V. C., L. M. Walter, and D. R. Peacor (2001), Early marine diagenesis of biogenic aragonite and Mg-calcite: New constraints from high-resolution STEM and AEM analyses of modern platform carbonates, Chem. Geol., 175, 221-248.

Jordan, R. W., and A. Kleijne (1994), A classification system for living coccolithophores, in Coccolithophores, edited by A. Winter an W. G. Siesser, pp. 83-105, Cambridge Univ. Press, New York.

Jordan, R. W., and A. Winter (2000), Assemblages of coccolithophorids and other living microplankton off the coast of Puerto Rico during January-May 1995, Mar. Micropaleontol., 39, 113-130.

Kallel, N., M. Paterne, J. C. Duplessy, C. Vergnaud Grazzini, C. Pujol, L. Labeyrie, M. Arnold, M. Fontugne, and C. Pierre (1997), Enhanced rainfall in the Mediterranean region during the last sapropel event, Oceanol. Acta, 20, 697-712

Kallel, N., J. C. Duplessy, L. Labeyrie, M. Fontugne, M. Paterne, and M. Montacer (2000), Mediterranean pluvial periods and sapropel formation over the last 200,000 years, Palaeogeogr. Palaeoclimatol. Palaeoecol., 157, 45-58.

Keenan, D. J. (2002), Why early-historical radiocarbon dates downwind from the Mediterranean are too early, Radiocarbon, 44, $225-237$.

Kemp, A. E. S., R. B. Pearce, I. Koizumi, J. Pike, and S. J. Rance (1999), The role of mat-forming diatoms in the formation of Mediterranean sapropels, Nature, 398, 57-61.

Kemp, A. E. S., J. Pike, R. B. Pearce, and C. B. Lange (2000), The "Fall dump"-A new perspective on the role of a "shade flora" in the annual cycle of diatom production and export flux, Deep Sea Res. Part II, 47, 2129-2154.

Kinsman, D. J. J. (1969), Interpretation of $\mathrm{Sr}^{2+}$ concentrations in carbonate minerals and rocks, J. Sediment. Petrol., 39, 486-507.

Kleijne, A. (1992), Extant Rhabdosphaeraceae (coccolithophorids, class Prymnesiophyceae) from the Indian Ocean, Red Sea, Mediterranean Sea and North Atlantic Ocean, Scr. Geol., 100, 1-63.

Klein, B., W. Roether, B. B. Manca, D. Bregant, V. Beitzel, V. Kovacevic, and A. Luchetta (1999), The large deep water transient in the eastern Mediterranean, Deep Sea Res. Part I, $46,371-414$

Knappertsbusch, M. (1993), Geographic distribution of living and Holocene coccolithophores in the Mediterranean Sea, Mar. Micropaleontol., 21, 219-247.

Krinsley, D., and R. Bieri (1959), Changes in the chemical composition of pteropod shells afte deposition on the sea floor, J. Paleontol., 33, 682-684.

Lein, A. Y., M. V. Ivanov, N. V. Pimenov, and M. B. Gulin (2002), Geochemical peculiarities of the carbonate constructions formed during microbial oxidation of methane under anaerobic conditions, Microbiology, 71, 78-90. 
Lourens, L. J., A. Antonarakou, F. J. Hilgen, A. A. M. Van Hoof, C. Vergnaud-Grazzini, and W. J. Zachariasse (1996), Evaluation of the Plio-Pleistocene astronomical timescale, Paleoceanography, 11, 391-413.

Macintyre, I. G., and R. P. Reid (1992), Comment on the origin of aragonite needle mud: A picture is worth a thousand words, J. Sediment. Petrol., 62, 1095-1097.

Macintyre, I. G., and R. P. Reid (1995), Crystal alteration in a living calcareous alga (Halimeda): Implications for studies in skeletal diagenesis, J. Sediment. Res., A65, 143-153.

Matsuoka, H., and H. Okada (1989), Quantitative analysis of Quaternary nannoplankton in the sub-tropical northwestern Pacific Ocean, Mar. Micropaleontol., 14, 97-118.

Melim, L. A., H. Westphal, P. K. Swart, G. P. Eberli, and A. Munnecke (2002), Questioning carbonate diagenetic paradigms: Evidence from the Neogene of the Bahamas, Mar. Geol., $185,27-53$

Mercone, D., J. Thomson, I. W. Croudace, G. Siani, M. Paterne, and S. Troelstra (2000), Duration of S1, the most recent sapropel in the eastern Mediterranean Sea, as indicated by AMS radiocarbon and geochemical evidence, Paleoceanography, 15, 336-347.

Milliman, J. D., and J. Müller (1973), Precipitation and lithification of magnesium calcite in the deep-sea sediments of the eastern Mediterranean Sea, Sedimentology, 20, 29-45.

Milliman, J. D., D. Friele, R. P. Steinen, and R. J. Wilber (1993), Great Bahama Bank aragonitic muds: Mostly inorganically precipitated, mostly exported, J. Sediment. Petrol., 63, 589-595.

Molfino, B., and A. McIntyre (1990a), Precessional forcing of nutricline dynamics in the equatorial Atlantic, Science, 249, 766-769.

Molfino, B., and A. McIntyre (1990b), Nutricline variation in the equatorial Atlantic coincident with the Younger Dryas, Paleoceanography, 59, $97-1008$.

Morse, J. W., F. J. Millero, V. Thurmond, E. Brown, and H. G. Ostlund (1984), The carbonate chemistry of Grand Bahama Bank waters-After 18 years another look, J. Geophys. Res., 89, 3604-3614.

Morse, J. W., Q. Wang, and M. Y. Tsio (1997), Influences of temperature and $\mathrm{Mg}: \mathrm{Ca}$ ratio on $\mathrm{CaCO}_{3}$ precipitates from sea water, Geology, $25,85-87$.

Morse, J. W., D. K. Gledhill, and F. J. Millero (2003), $\mathrm{CaCO}_{3}$ precipitation kinetics in waters from the Great Bahama Bank: Implications for the relationship between bank hydrochemistry and whitings, Geochim. Cosmochim. Acta, 67, $2819-2826$

Mucci, A. (1983), The solubility of calcite and aragonite in seawater at various salinities, temperatures and one atmosphere total pressure, Am. J. Sci., 283, 780-799.

Mucci, A., B. Sundby, M. Gehlen, T. Arakaki, S. Zhong, and N. Silverberg (2000), The fate of carbon in continental shelf sediments of eastern Canada: A case study, Deep Sea Res. Part II, 47, 733-760.

Müller, A., M. K. Gagan, and M. T. McCulloch (2001), Early marine diagenesis in corals and geochemical consequences for paleoceanographic reconstructions, Geopyhs. Res. Lett., $28,4471-4474$

Negri, A., and S. Giunta (2001), Calcareous nannofossil paleoecology in the sapropel S1 of the eastern Ionian Sea: Paleoceanographic implications, Palaeogeogr. Palaeoclimatol. Palaeoecol., 169, 101-112.

Negri, A., L. Capotondi, and J. Keller (1999), Calcareous nannofossils, planktonic foraminifera and oxygen isotopes in the late Quaternary sapropels of the Ionian Sea, Mar. Geol., 157, $89-103$

Okada, H. (2000), Neogene and Quaternary calcareous nannofossils from the Blake Ridge Sites 994, 995, and 997, Proc. Ocean Drill. Program Sci. Results, 164, 331-341.

Okada, H., and S. Honjo (1973), The distribution of oceanic coccolithophorids in the Pacific Deep Sea Res., 20, 355-374.

Okada, H., and M. Matsuoka (1996), Lowerphotic nannoflora as an indicator of the late Quaternary monsoonal palaeo-record in the tropical Indian Ocean, in Proceedings of the International Conference on ODP and the Marine Biosphere, edited by A. Moguilevsky and R. Whatley, pp. 231-245, Aberystwyth, 19-21 April 1994.

Okada, H., and P. Wells (1997), Late Quaternary nannofossil indicators of climate change in two deep-sea cores associated with the Leeuwin Current off Western Australia, Palaeogeogr Palaeoclimatol. Palaeoecol., 131, 413-432.

Passier, H. F., J. J. Middelburg, B. J. H. Van Os, and G. J. De Lange (1996), Diagenetic pyritisation under eastern Mediterranean sapropels caused by downward sulphide diffusion, Geochim. Cosmochim. Acta, 60 $751-763$.

Patterson, W. P., and L. M. Walter (1994), Syndepositional diagenesis of modern platform carbonates-Evidence from isotopic and minor element data, Geology, 22, 127-130.

Rasmussen, T. L. (1991), Benthic and planktonic foraminifera in relation to the early Holocene stagnation in the Ionian Basin, central Mediterranean, Boreas, 20, 357-376.

Reardon, E. J., and D. K. Armstrong (1987), Celestite $\left(\mathrm{SrSO}_{4(\mathrm{~S})}\right)$ solubility in water, seawater and $\mathrm{NaCl}$ solution, Geochim. Cosmochim. Acta, 51, 63-72.

Reeder, M., R. G. Rothwell, D. A. V. Stow, G. Kahler, and N. H. Kenyon (1998), Turbidite flux, architecture and chemostratigraphy of the Herodotus Basin, Levantine Sea, SE Mediterranean, in Geological Processes on Continental Margins: Sedimentation, Mass Wasting and Stability, Spec. Publ., vol. 129, edited by M. S. Stoker, D. Evans, and A. Cramp, pp. 19-41, Geol. Soc., London.

Reid, R. P., and I. G. Macintyre (1998), Carbonate recrystallization in shallow marine environments: A widespread diagenetic process forming micritized grains, J. Sediment. Res., $68,928-946$.

Reimer, P. J., and F. G. McCormac (2002), Marine radiocarbon reservoir corrections for the Mediterranean and Aegean Seas, Radiocarbon, 44, 159-166.

Ribaud-Laurenti, A., B. Hamelin, L. Montaggioni, and D. Cardinal (2001), Diagenesis and its impact on $\mathrm{Sr} / \mathrm{Ca}$ ratio in Holocene Acropora corals, Int. J. Earth Sci., 90, 438-451.

Rickaby, R. E. M., D. P. Schrag, I. Zondervan, and U. Riebesell (2002), Growth rate dependence of $\mathrm{Sr}$ incorporation during calcification of Emiliania huxleyi, Global Biogeochem. Cycles, 16(1), 1006, doi:10.1029/ 2001GB001408.

Robbins, L. L., and P. L. Blackwelder (1992), Biochemical and ultrastructural evidence for the origin of whitings: A biologically induced calcium carbonate precipitation mechanism, Geology, 20, 464-468.

Roether, W., and R. Well (2001), Oxygen consumption in the eastern Mediterranean, Deep Sea Res. Part I, 48, 1535-1551.

Rohling, E. J. (1994), Review and new aspects concerning the formation of eastern Mediterranean sapropels, Mar. Geol., 12, 21-28.

Rohling, E. J. (1999), Environmental control on Mediterranean salinity and delta O-18, Paleoceanography, 14, 706-715.

Rohling, E. J., and W. W. C. Gieskes (1989), Late Quaternary changes in Mediterranean Intermediate Water density and formation rate, Paleoceanography, 4, 531-545.

Rossignol-Strick, M. (1999), The Holocene climatic optimum and pollen records of sapropel 1 in the eastern Mediterranean, 9000-6000 BP, Quat. Sci. Rev., 18, 515-530.

Rossignol-Strick, M., W. Nesteroff, P. Olive, and C. Vergnaud-Grazzini (1982), After the deluge-Mediterranean stagnation and sapropel formation, Nature, 295, 105-110.

Rushdi, A. I., J. McManus, and R. W. Collier (2000), Marine barite and celestite saturation in seawater, Mar. Chem., 69, 19-31.

Rutten, A., and G. J. de Lange (2002), A novel selective extraction of barite, and its application to eastern Mediterranean sediments, Earth Planet. Sci. Lett., 198, 11-24.

Schenau, S. J., A. Antonarakou, F. J. Hilgen, L. J. Lourens, I. A. Nijenhuis, C. H. van der Weijden, and W. J. Zachariasse (1999), Organicrich layers in the Metochia section (Gavdos, Greece): Evidence for a single mechanism of sapropel formation during the past $10 \mathrm{My}$, Mar. Geol., 153, 117-135.

Shen, C. C., D. W. Hastings, T. P. Lee, C.-H. Chiu, M.-Y. Lee, K. Y. Wei, and R. L. Edwards (2001), High precision glacial-interglacial benthic foraminiferal $\mathrm{Sr} / \mathrm{Ca}$ records from the eastern equatorial Atlantic Ocean and Caribbean Sea, Earth Planet. Sci. Lett., 190, $197-$ 209.

Shinn, E. A., R. P. Steinen, B. H. Lidz, and P. K. Swart (1989), Whitings, a sedimentologic dilemma, J. Sediment. Petrol., 59, $147-161$.

Stoll, H., and D. Schrag (1999), Coccolith $\mathrm{Sr} / \mathrm{Ca}$ as a new indicator of coccolithophorid calcification and growth rate, Geochem. Geophys. Geosyst., 1(5), doi:10.1029/1999GC000015.

Stoll, H. M., and P. Zivieri (2002), Separation of monospecific and restricted coccolith assemblages from sediments using differential settling velocity, Mar. Micropaleontol., 46, 209-221.

Stuiver, M., and T. F. Braziunas (1993), Modelling atmospheric ${ }^{14} \mathrm{C}$ influences and ${ }^{14} \mathrm{C}$ ages of marine samples to $10,000 \mathrm{BC}$, Radiocarbon, 35, 137-189.

Takahashi, K., and H. Okada (2000), The paleoceanography for the last 30,000 years in the southeastern Indian Ocean by means of calcareous nannofossils, Mar. Micropaleontol., 40, $83-103$.

Thomson, J., N. C. Higgs, T. R. S. Wilson, I. W. Croudace, G. J. de Lange, and P. J. M. van Santvoort (1995), Redistribution and geochemical behaviour of redox-sensitive elements around $\mathrm{S} 1$, the most recent eastern Mediterranean sapropel, Geochim. Cosmochim. Acta, 59, 3487-3501.

Thompson, J., S. Schultze-Lam, T. J. Beveridge, and D. J. DesMarais (1997), Whiting events Biogenic origin due to the photosynthetic 
activity of cyanobacterial picoplankton, Limnol. Oceanogr., 42, 133-141.

Thomson, J., D. Mercone, G. J. de Lange, and P. J. M. van Santvoort (1999), Review of recent advances in the interpretation of eastern Mediterranean sapropel S1 from geochemical evidence, Mar. Geol., 153, 77-89.

Troelstra, S. R., G. M. Ganssen, K. van der Borg, and A. M. F. de Jong (1991), A late Quaternary stratigraphic framework for eastern Mediterranean sapropel $\mathrm{S} 1$ based on AMS ${ }^{14} \mathrm{C}$ dates and stable oxygen isotopes, Radiocarbon, 33, 1521

van Os, B. J. H., L. J. Lourens, F. J. Hilgen, G. J. de Lange, and L. Beaufort (1994), The formation of Pliocene sapropels and carbonate cycles in the Mediterranean: Diagenesis, dilution and productivity, Paleoceanography, 9, 601-617.

van Santvoort, P. J. M., G. J. de Lange, J. Thomson, H. Cussen, T. R. S. Wilson, M. D. Krom, and K. Strohle (1996), Active post-depositional oxidation of the most recent sapropel (S1) in the eastern Mediterranean, Geochim. Cosmochim. Acta, 60, 4007-4024.

van Santvoort, P. J. M., G. J. de Lange, J. Thomson, S. Colley, F. J. R. Meysman, and C. P. Slomp (2002), Oxidation and origin of organic matter in surficial eastern Mediterranean hemipelagic sediments, Aquat. Geochem., 8, 153-175.

Varol, O., and S. D. Houghton (1996), A review and classification of fossil didemnid ascidian spicules, J. Micropaleontol., 15, 135-149.

Wassmann, P., J. E. Ypma, and A. Tselepides (2000), Vertical flux of faecal pellets and microplankton on the shelf of the oligotrophic Cretan Sea (NE Mediterranean Sea), Progr. Oceanogr., 46, 241-258.

Wehausen, R., and H.-J. Brumsack (2000), Chemical cycles in Pliocene sapropel-bearing and sarpopel-barren eastern Mediterranean sediments, Palaeogeogr. Palaeoclimatol. Palaeoecol., 158, 325-352.

Wilkinson, B. H., and R. K. Given (1986), Secular variation in abiotic marine carbonates - Constraints on Phanerozoic atmospheric carbon dioxide contents and oceanic $\mathrm{Mg} / \mathrm{Ca}$ ratios, J. Geol., 94, 321-333.

Ziveri, P., A. Rutten, G. J. de Lange, J. Thomson, and C. Corselli (2000), Present-day coccolith fluxes recorded in central eastern Mediterranean sediment traps and surface sediments,
Palaeogeogr. Palaeoclimatol. Palaeoecol., 158, 175-195.

S. E. Calvert, Department of Earth and Ocean Sciences, 6270 University Boulevard, University of British Columbia, Vancouver, BC V6T 1Z4, Canada.

D. Crudeli, Institute for Geosciences, ChristianAlbrechts-Universitat Kiel, Ludewig-Meynstrasse 10, D-24118 Kiel, Germany.

G. J. de Lange and C. P. Slomp, Utrect University, Faculty of Earth Sciences, Budapestlaan 4, N-3584 CD Utrecht, Netherlands.

E. Erba, Department of Earth Sciences, University of Milan, Via Mangiagalli 34, I-20133 Milan, Italy.

C. Corselli, Department of Geological Sciences and Geotechnologies, Milano-Bicocca University, Piazza della Scienza 4, I-20126 Milan, Italy.

J. Thomson, Southampton Oceanography Centre, Empress Dock, Southampton SO14 3ZH, UK. ( jth@soc.soton.ac.uk) 